\title{
mSin3A corepressor regulates diverse transcriptional networks governing normal and neoplastic growth and survival
}

\author{
Jan-Hermen Dannenberg, ${ }^{1,4}$ Gregory David, ${ }^{1,3,4}$ Sheng Zhong, ${ }^{2}$ Jaco van der Torre, ${ }^{1}$ Wing H. Wong, ${ }^{2}$ \\ and Ronald A. DePinho ${ }^{1,5}$ \\ ${ }^{1}$ Department of Medical Oncology, Dana Farber Cancer Institute; Departments of Medicine and Genetics, Harvard Medical \\ School, Boston, Massachusetts 02115, USA; ${ }^{2}$ Department of Statistics, Stanford University, Stanford, California 94305, USA
}

mSin3A is a core component of a large multiprotein corepressor complex with associated histone deacetylase (HDAC) enzymatic activity. Physical interactions of $\mathbf{m S i n} 3 \mathrm{~A}$ with many sequence-specific transcription factors has linked the mSin $3 \mathrm{~A}$ corepressor complex to the regulation of diverse signaling pathways and associated biological processes. To dissect the complex nature of $\mathrm{mSin} 3 \mathrm{~A}^{\prime} \mathrm{s}$ actions, we monitored the impact of conditional mSin $3 \mathrm{~A}$ deletion on the developmental, cell biological, and transcriptional levels. mSin $3 \mathrm{~A}$ was shown to play an essential role in early embryonic development and in the proliferation and survival of primary, immortalized, and transformed cells. Genetic and biochemical analyses established a role for mSin3A/HDAC in p53 deacetylation and activation, although genetic deletion of p53 was not sufficient to attenuate the mSin3A null cell lethal phenotype. Consistent with mSin3A's broad biological activities beyond regulation of the p53 pathway, time-course gene expression profiling following $\mathrm{mSin} 3 \mathrm{~A}$ deletion revealed deregulation of genes involved in cell cycle regulation, DNA replication, DNA repair, apoptosis, chromatin modifications, and mitochondrial metabolism. Computational analysis of the mSin $3 \mathrm{~A}$ transcriptome using a knowledge-based database revealed several nodal points through which mSin3A influences gene expression, including the Myc-Mad, E2F, and p53 transcriptional networks. Further validation of these nodes derived from in silico promoter analysis showing enrichment for Myc-Mad, E2F, and p53 cis-regulatory elements in regulatory regions of up-regulated genes following $\mathrm{mSin} 3 \mathrm{~A}$ depletion. Significantly, in silico promoter analyses also revealed specific cis-regulatory elements binding the transcriptional activator Stat and the ISWI ATP-dependent nucleosome remodeling factor Falz, thereby expanding further the mSin3A network of regulatory factors. Together, these integrated genetic, biochemical, and computational studies demonstrate the involvement of $\mathrm{mSin} 3 \mathrm{~A}$ in the regulation of diverse pathways governing many aspects of normal and neoplastic growth and survival and provide an experimental framework for the analysis of essential genes with diverse biological functions.

[Keywords: Histone modifications; knock-out; mSin3 complex; mSin3A; transcriptional regulation; tumorigenesis]

Supplemental material is available at http://www.genesdev.org.

Received December 6, 2004; revised version accepted May 20, 2005.

Chromatin dynamics impact virtually all known biological processes governing normal mammalian development and the growth and survival of primary and cancer cells. Histones are the central structural elements of

\footnotetext{
${ }^{3}$ Present address: Department of Pharmacology, New York University, School of Medicine, New York, NY, 10016 USA.

${ }^{4}$ These authors equally contributed to this work.

${ }^{5}$ Corresponding author.

E-MAIL ron depinho@dfci.harvard.edu; FAX (617) 632-6069.

Article and publication are at http://www.genesdev.org/cgi/doi/10.1101/ gad.1286905
}

chromatin, and their $\mathrm{N}$-terminal tails are subject to covalent modifications by the opposing actions of histone acetyltransferases (HATs) and histone deacetylases (HDACs) as well as other enzymatic activities. This reversible acetylation, along with other histone modifications, alters either focal or global chromatin domains and thereby influences the activation or repression of gene transcription, activities of the repair DNA machinery, formation of structures required for proper chromosome segregation among other biological processes (for review, see Fischle et al. 2003 and references therein). 
These biological processes are affected through histone-modifying enzymes whose activities are targeted to specific sites on the DNA via their association with corepression scaffolding molecules that can be recruited by sequence-specific binding proteins such as transcription factors. The mammalian Sin 3 proteins, mSin $3 \mathrm{~A}$ and $\mathrm{mSin} 3 \mathrm{~B}$, represent prototypical corepressor molecules that were discovered initially through their direct interaction with the sequence-specific transcriptional repressors of the Myc family network, Mad1 and Mxil (Ayer et al. 1995; Schreiber-Agus et al. 1995; Laherty et al. 1997) and later shown to associate with HDAC1 and HDAC2 within a large multiprotein complex, the Sin3/HDAC corepressor complex (for review, see Schreiber-Agus and DePinho 1998; Ayer 1999; Knoepfer and Eisenman 1999; Silverstein and Ekwall 2004). Subsequent efforts have also revealed that the mSin3/HDAC proteins are recruited by an expanding array of factors involved primarily in transcriptional regulation including p53 (Murphy et al. 1999), Ikaros (Koipally et al. 1999), REST (Huang et al. 1999), and E2F4 (Rayman et al. 2002), contributing to repression of their target genes.

$\mathrm{mSin} 3 \mathrm{~A}$ and $\mathrm{mSin} 3 \mathrm{~B}$ proteins share extensive similarity within their four paired amphipathic helix (PAH) protein-interaction domains. The presence of two highly related mSin 3 homologs in mammals and other species (Dang et al. 1999; Silverstein and Ekwall 2004), suggests that each $\mathrm{mSin} 3$ homolog serves separable functions. The mSin 3 corepressor complex's central enzymatic activity is imparted through its Class I HDAC constituents, HDAC1 and HDAC2. The maintenance of mSin3associated HDAC activity is dependent on another integral component, mSds3, whose ortholog in Saccharomycese cerevisiae is epistatic to the yeast $\sin 3 p$ and HDAC orthologs (Vannier et al. 1996; Alland et al. 2002). Additional core $\mathrm{mSin} 3 / \mathrm{HDAC}$ proteins include the retinoblastoma-associated proteins, RbAp46 and RbAp48, which are thought to stabilize interactions with the mSin3 complex and the nucleosome, mSin3-associated proteins (SAPs: SAP18, SAP30, SAP130, and SAP180), RBP1, p33ING1b, and BRMS1, which have been isolated through biochemical means and remain the focus of ongoing functional investigations (for review, see Ayer 1999; Kuzmichev et al. 2002; Lai et al. 2001; Skowyra et al. 2001; Fleischer et al. 2003; Meehan et al. 2004).

As initially reported for the Mad family, the $\mathrm{mSin} 3 /$ HDAC complex also drives the repression activity of numerous other sequence-specific transcription factors whose list has expanded considerably in the past few years. Among those factors that recruit the $\mathrm{mSin} 3 /$ HDAC complex, several are involved in cell survival and apoptosis, thereby linking this complex activity to cancer-relevant processes. For instance, tumor-suppressor proteins, including p53 (Murphy et al. 1999), pRb (Brehm et al. 1998; Luo et al. 1998; Magnaghi-Jaulin et al. 1998; Lai et al. 2001), and Menin (Kim et al. 2003) have been shown to repress their target genes through interaction with the mSin3/HDAC complex. Moreover, aberrant recruitment of this complex by altered transcription factors has been shown to be pathogenetic in several human cancers, such as Acute Promyelocytic Leukemia and Acute Myeloid Leukemia (for review, see Melnick and Licht 2002).

In addition to its role in transcriptional repression, new activities for the mSin3/HDAC complex are continually uncovered in diverse model organisms. For example, $S$. cerevisiae $\sin 3 \mathrm{p}$ has been shown to participate in the transcriptional activation (as opposed to repression) of MAPK Hogl target genes upon osmotic stress (De Nadal et al. 2004), and recent links have been forged between $S$. cerevisiae sin3 and DNA replication (Aparicio et al. 2004). S. cerevisiae and Caenorhabditis elegans Sin 3 molecules have also been implicated in the DNA damage-repair process in a transcription-independent manner (Pothof et al. 2003; Jazayeri et al. 2004). Finally, several Sin3-associated molecules have been shown to participate in activities other than transcriptional regulation including a role for the Sin 3 complex in centromere function and genomic stability in both yeast and mammals. Along these lines, genetic inactivation of Pst1 (the homolog of $\mathrm{mSin} 3 \mathrm{~A}$ in fission yeast) or $\mathrm{mSds} 3$ (an essential component of the mSin3/HDAC complex in mouse cells) results in loss of specific chromatin modifications at centromeric or pericentromeric loci, and ultimately, impaired chromosomal segregation (David et al. 2003; Nakayama et al. 2003; Silverstein et al. 2003).

Here, against this backdrop of significant knowledge of the $\mathrm{mSin} 3$ corepressor complex, we have sought to better define the biological roles of mSin $3 \mathrm{~A}$ in normal mammalian development, the growth and survival of primary and cancer cells, and the regulation of transcriptional networks. To this end, a conditional mSin3A knock-out model system, biochemical analyses, and computational methods were used in an integrated manner to understand the biological impact of zygotic and somatic deletion of $\mathrm{mSin} 3 \mathrm{~A}$ in vivo and in cultured primary and transformed cells.

\section{Results}

mSin3A is essential for early embryonic development and for cellular proliferation and survival

Gene targeting and chimera formation were used to generate a conditional $m \operatorname{Sin} 3 A$ allele $\left(m \operatorname{Sin} 3 A^{L}\right)$ in the mouse germline (Fig. 1A,B) that retained wild-type function, as evidenced by normal expression of $\mathrm{mSin} 3 \mathrm{~A}$ and the lack of a phenotype in mice and derivative cells that were heterozygous or homozygous for $m \operatorname{Sin} 3 A^{L}$ (Fig. 1C; data not shown). Moreover, $m \operatorname{Sin} 3 A^{+/-}$mice, generated from $E 2 A$-Cre and $m \operatorname{Sin} 3 A^{L /+}$ matings, displayed normal genotype distribution patterns and were outwardly healthy and grossly indistinguishable from $\mathrm{mSin} 3 \mathrm{~A}^{+/+}$ littermates up to $1.5 \mathrm{yr}$ of age. While $\mathrm{mSin} 3 A^{+/-}$intercrosses readily generated $m \operatorname{Sin} 3 A^{-/-}$blastocysts, nullizygotes were not present on embryonic day 6.5 (E6.5) and thereafter, indicating that $\mathrm{mSin} 3 \mathrm{~A}$ serves an essential role in early development circa at peri-implantation (Fig. 1D).

The early lethal phenotype associated with zygotic ho- 
A

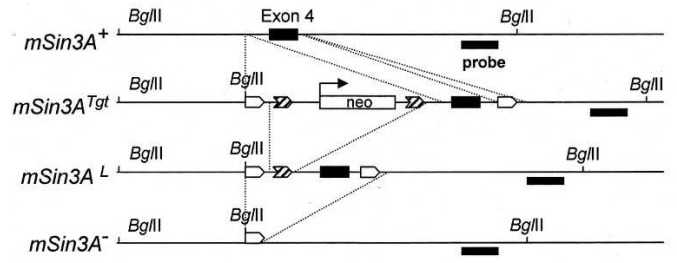

C

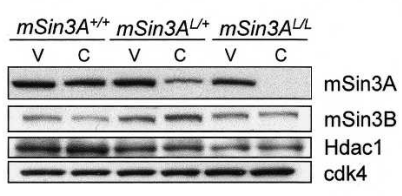

B

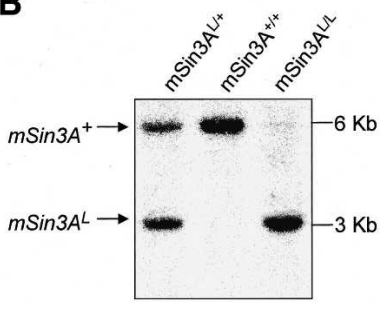

D

\begin{tabular}{c|cccc} 
& $E 3.5$ & $E 6.5$ & $E 10.5$ & $P 5$ \\
\hline$m \sin 3 A^{+/+}$ & 5 & 2 & 7 & 10 \\
$m \sin 3 A^{+/-}$ & 9 & 4 & 12 & 20 \\
$m \sin 3 A^{--}$ & 4 & 0 & 0 & 0 \\
\hline $\mathrm{N}=$ & 17 & 6 & 19 & 30
\end{tabular}

Figure 1. $\mathrm{mSin} 3 \mathrm{~A}$ deficiency results in embryonic lethality. (A) Schematic representation of the wild-type $\left(m \operatorname{Sin} 3 A^{+}\right)$, targeted $\left(m \operatorname{Sin} 3 A^{T g t}\right)$, floxed $\left(m \operatorname{Sin} 3 A^{L}\right)$, and null-allele $\left(m \operatorname{Sin} 3 A^{-}\right)$of $\mathrm{mSin} 3 \mathrm{~A}$. Upon deletion of the neomycin selection cassette flanked by Frt sites (striped arrowheads), exon 4 was left flanked by LoxP sites (open arrowheads). (B) Southern blot analysis of BglII-digested DNA isolated from $\mathrm{mSin} 3 \mathrm{~A}$-targeted ES cells using a $3^{\prime}$ fragment indicated in $A$ as a probe. $(C)$ Western blot analysis of protein extracts from $m \operatorname{Sin} 3 A^{+/+}, m \operatorname{Sin} 3 A^{L /+}$, and $m \operatorname{Sin} 3 A^{\mathrm{L} / \mathrm{L}} \mathrm{MEFs}$ infected with either vector-expressing $(\mathrm{V})$ or Cre-recombinase-expressing (C) virus for $\mathrm{mSin} 3 \mathrm{~A}, \mathrm{mSin} 3 \mathrm{~B}$, and $\mathrm{Hdac} 1$. Cdk4 served as a loading control. $(D)$ Genotype distribution of offspring and embryos at E3.5, E6.5, E10.5, and post-natal day 5 (P5), as a result of $m \operatorname{Sin} 3 A^{+/-}$intercrosses.

mozygous deletion of $m \operatorname{Sin} 3 A$ prompted somatic conditional $m S$ Sin $3 A$ deletion studies in primary cell cultures. To that end, Cre-encoding retroviruses were used to infect $m \operatorname{Sin} 3 A^{L / L}$ mouse embryonic fibroblasts (MEFs), resulting in steady and complete depletion of mSin3A protein only in the $m \operatorname{Sin} 3 A^{L / L}$ MEFs over a 5-d period (Fig. 1C). While the well-recognized modest Cre-induced stasis was evident in $\mathrm{mSin} 3 \mathrm{~A}^{+/+} \mathrm{MEFs}$, Cre expression in $m S i n 3 A^{L / L}$ MEFs was associated with profound growth arrest and increased apoptosis, as revealed by microscopic inspection, TUNEL assay, and by FACS profiles with a sub-G $\mathrm{G}_{1}$ peak (Fig. 2; Supplementary Fig. 1). In addition to a $\mathrm{G}_{2} / \mathrm{M}$ arrest, the BrdU-PI FACS profiles of mSin $3 A^{-1-}$ cultures revealed a subpopulation with S-phase DNA content, yet no BrdU incorporation (Fig. 2C, arrow)-a profile consistent with unscheduled DNA replication with subsequent triggering of an S-phase checkpoint.

To solidify the link between mSin3A deficiency and the above cellular defects, ectopic expression of wildtype $m \operatorname{Sin} 3 A$, but not an irrelevant gene (luciferase), was able to eliminate the aforementioned cellular phenotypes associated with deletion of endogenous $m \operatorname{Sin} 3 A$ (Supplementary Fig. 2). Finally, Western blot analyses of mSin3A-deficient cultures showed no appreciable upregulation of mSin3B or HDAC1 (Fig. 1C), although transcriptional up-regulation of several genes encoding other mSin3A-associated factors was detected, suggesting potential gene regulatory interactions (see transcriptional profiles below). The cell lethal phenotype upon mSin3A depletion, coupled with continued expression of the structurally related $\mathrm{mSin} 3 \mathrm{~B}$, underscores that $\mathrm{mSin} 3 \mathrm{~A}$ serves separable and essential cell physiological functions.

Distinctive roles for $\mathrm{mSin} 3 \mathrm{~A}$ and $\mathrm{mSds} 3$ in chromosome biology

Previous yeast studies have suggested a strong epistatic relationship between Sin3 and its associated HDAC and
Sds 3 components. In mammals, the $m \operatorname{Sin} 3 A^{-/-}$and $m S d s 3^{-I-}$ phenotypes appeared to be somewhat overlapping, as inferred by early embryonic lethality and cellular growth arrest and apoptosis. In particular, both $\mathrm{mSin} 3 \mathrm{~A}^{-/-}$and $\mathrm{mSds} 3^{-/-}$cells showed $\mathrm{G}_{2} / \mathrm{M}$ arrest profiles, which raised the possibility that $\mathrm{mSin} 3 \mathrm{~A}$ may also be involved in chromosome dynamics as reported recently for mSds3 (David et al. 2003). As reported previously (David et al. 2003), $m S d s 3^{-/-}$cells exhibited an increase in multinucleated cells and rampant aneuploidy due to impaired chromosome segregation. In contrast, $m \operatorname{Sin} 3 A^{-/-}$MEFs showed no increase in multinucleated cells and possessed relatively normal chromosome counts (Fig. 3A; data not shown). Reminiscent of $\mathrm{mSds} 3^{-/-}$cells, $>75 \%$ of the $\mathrm{mSin} 3 \mathrm{~A}^{-/-}$cells exhibited diffuse HP1 $\alpha$ signal throughout the nucleus, rather than the normal concentrated signal within DAPI-stained heterochromatin structures (Fig. 3C).

Despite these abnormal HP1 $\alpha$ patterns (and consistent with normal chromosome counts), immunofluorescence studies revealed proper heterochromatin localization of methylated Lys 9 of histone H3 (meH3K9) and Lys 20 at histone $\mathrm{H} 4$ (meH4K20), as well as hypoacetylated Lys 5 and Lys 12 of histone H4 (AcH4K5 and AcH4K12) (Fig. $3 \mathrm{~B}, \mathrm{C}$; data not shown). Additionally, no differences were observed in overall acetylation status of Lys 5, Lys 8, Lys 12 , and Lys 16 of histone $\mathrm{H} 4$, indicating that $\mathrm{mSin} 3 \mathrm{~A}$ is not involved in global deacetylation of histone $\mathrm{H} 4$ (data not shown). Notably, this $m \operatorname{Sin} 3 A^{-/-}$heterochromatin profile is highly reminiscent of Orc2 (origin of replication 2)-depleted cells that similarly show a DNA replication block, $\mathrm{G}_{2} / \mathrm{M}$ arrest, and loss of $\mathrm{HP} 1 \alpha$ pericentric heterochromatin localization, yet lack of chromosomal instability (Prasanth et al. 2004). Accordingly, Orc2 failed to localize to pericentric heterochromatin in $m \operatorname{Sin} 3 A^{-/-}$cells (Fig. $3 \mathrm{D}$ ), pointing to a link between Orc2 and mSin $3 \mathrm{~A}$ in the proper targeting of $\mathrm{HP} 1 \alpha$ to pericentric heterochromatin. However, as Orc2 disappears from pericentric heterochromatic during late $G_{2} /$ $\mathrm{M}$, one cannot exclude the possibility that Orc2 is not 
Dannenberg et al.

A
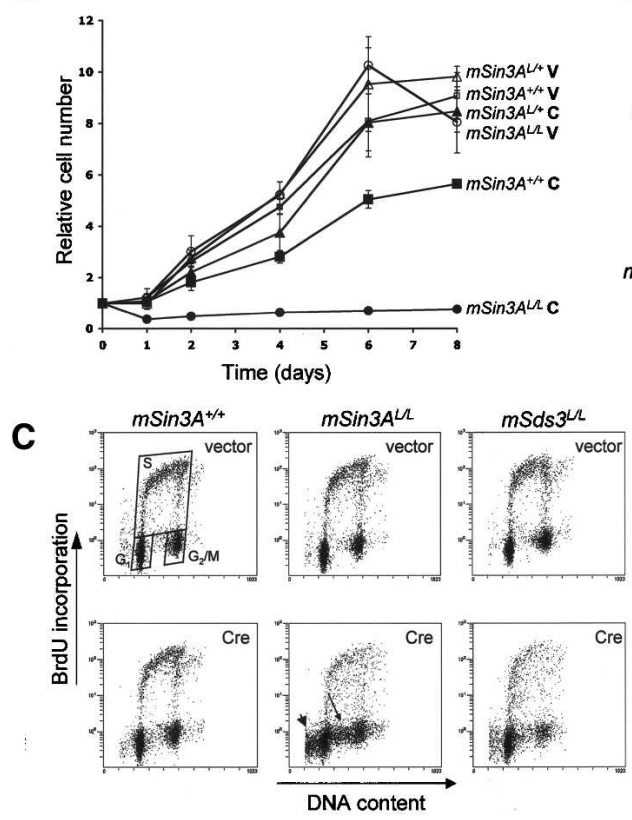

B
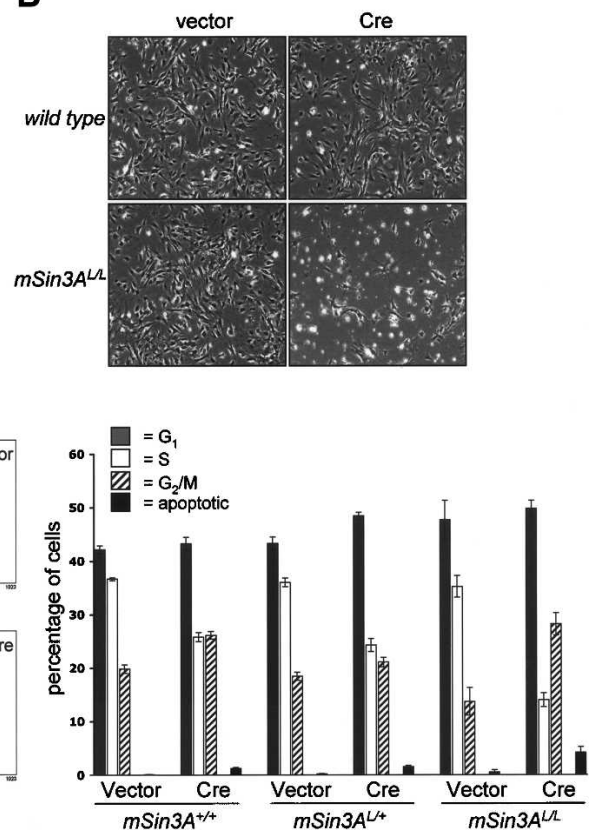

Figure 2. mSin3A deficiency reduces proliferative capacity in MEFs by increased apoptosis, block in DNA replication, and $\mathrm{G}_{2} / \mathrm{M}$ arrest. (A) Growth curve analysis of $m \operatorname{Sin} 3 A^{+/+}$(squares), $m \operatorname{Sin} 3 A^{L /+}$ (triangles), and $m \operatorname{Sin} 3 A^{L / L}$ (circles) MEFs infected with either vector-expressing (open) or Cre-recombinase-expressing (filled) virus. The figure shows a representative of three independent experiments, each performed in triplicate. Error bars indicate the standard deviation of the mean. Note that time-point 0 indicates $4 \mathrm{~d}$ after the beginning of the infection. (B) MEF cell cultures of indicated genotypes $5 \mathrm{~d}$ after infection with either vector- or Cre-recombinaseexpressing viruses. $(C)$ BrdU-PI FACS analysis of $m \operatorname{Sin} 3 A^{+/+}, m S i n 3 A^{L / L}$, and $m S d s 3^{L / L} \mathrm{MEFs}$ infected with vector- or Cre-recombinaseexpressing viruses. Notice the presence of apoptotic cells (arrowhead) and S-phase-arrested cells (arrow) in $m S$ in $3 A^{\mathrm{L} / \mathrm{L}}$-expressing Cre-recombinase. $(D)$ Percentages of $G_{1}, S, G_{2} / M$, and sub- $G_{1}$ (apoptotic) phases in indicated MEF cultures under normal culture conditions. The figure shows a representative of three independent experiments, each performed in triplicate.

present at pericentric heterochromatin as $\mathrm{mSin} 3 \mathrm{~A}^{-/-}$ cells are constrained at the late $\mathrm{G}_{2} / \mathrm{M}$ phase. In summary, $\mathrm{mSin} 3 \mathrm{~A}$ and $\mathrm{mSds} 3$ deficiencies differentially impact on cell cycle kinetics, as evidenced by the specific link of mSin3A to DNA replication processes and the seminal role of Sds3 in chromosome segregation. These differences in chromosome dynamics suggest that either $\mathrm{mSds} 3$ functions independently of mSin3A, or that $\mathrm{mSin} 3 \mathrm{~A}$ and $\mathrm{B}$ homologs serve overlapping functions in these specific cellular processes.

\section{$m$ Sin $3 A$ regulation of the $p 53-p 21^{\text {Cip } 1}$ axis}

The cell cycle arrest and apoptosis phenotypes of $\mathrm{mSin} 3 \mathrm{~A}$ deficiency prompted an in-depth genetic analysis of the p53-p21 ${ }^{\text {Cip1 }}$ pathway, particularly in the light of previous reports revealing (1) mSin3A-p53 physical association (Murphy et al. 1999), (2) modulation of p53 acetylation and transcriptional activity upon genotoxic stress (Sakaguchi et al. 1998), and (3) capacity of HDAC inhibitors or genetic deletion of Hdac1 to induce the p53 transcriptional target p21 ${ }^{\mathrm{Cip} 1}$ (Lagger et al. 2002, 2003; for review, see Johnstone and Licht 2003). In line with these observations, we observed consistent induction of p2 $1^{\text {Cip1 }}$ expression upon Cre-mediated deletion of mSin3A (Fig. 4A,B). Indeed, chromatin immunoprecipitation (ChIP) experiments revealed the presence of
mSin3A on the promoter of $p 21^{\text {Cip } 1}$ (data not shown). While $m \operatorname{Sin} 3 A^{L / L}$ MEFs infected with Cre retroviruses showed no significant additional increase in $\mathrm{p} 21^{\mathrm{Cip} 1}$ protein levels, independent experiments revealed hyperacetylation of p53 on Lys 317 and Lys 379, upon treatment with doxorubicin (Fig. 4B). These data strongly suggest that $\mathrm{mSin} 3 \mathrm{~A}$ regulates the $\mathrm{p} 53-\mathrm{p} 21^{\mathrm{Cip} 1}$ axis on two levels; it represses $p 21^{\text {Cip } 1}$ transcription by regulating acetylation of histones in the promoter of $p 21^{\text {Cip } 1}$ and regulates p53 activity via deacetylation upon genotoxic stress.

To substantiate the $\mathrm{mSin} 3 \mathrm{~A}-\mathrm{p} 53-\mathrm{p} 21^{\mathrm{Cip} 1}$ interrelationship on the genetic level, $\operatorname{mSin} 3 A^{+/+} p 53^{-/-}$, $m \operatorname{Sin} 3 A^{L /+} p 53^{-/-}$and $m \operatorname{Sin} 3 A^{L /-} p 53^{-/-}$MEFs were infected with either Cre or control retrovirus, and subsequently analyzed for DNA damage-induced p21 $\mathrm{cip} 1$ induction and associated effects on proliferation and cell cycle. $\mathrm{p} 21^{\mathrm{Cip} 1}$ induction was found to be robust in $m \operatorname{Sin} 3 A^{-/-} p 53^{+/+}$cells and totally abolished in $\mathrm{mSin} 3 \mathrm{~A}^{-/-} \mathrm{p} 53^{-/-}$cells (Fig. 4A), indicating that p53 is responsible for genotoxin-induced $\mathrm{p} 21^{\mathrm{Cip} 1}$ up-regulation in the setting of $\mathrm{mSin} 3 \mathrm{~A}$ deficiency. Despite this, p53 deficiency did not alleviate the $m \operatorname{Sin} 3 A^{-/-}$phenotypes of poor cell proliferation, reduced S-phase and increased $\mathrm{G}_{2} / \mathrm{M}$ fractions, block in DNA replication, and marked apoptosis (Fig. 4C-E; Supplementary Fig. 3A). Additionally, functional inactivation of both the p53 and $\mathrm{pRb}$ 
A

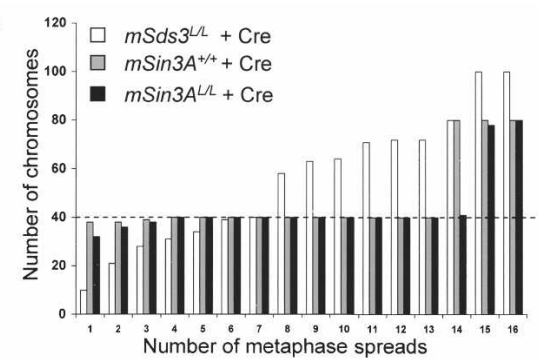

$c$

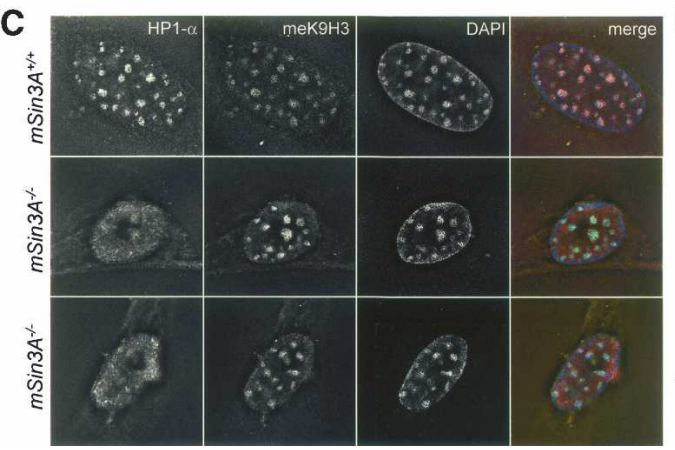

B

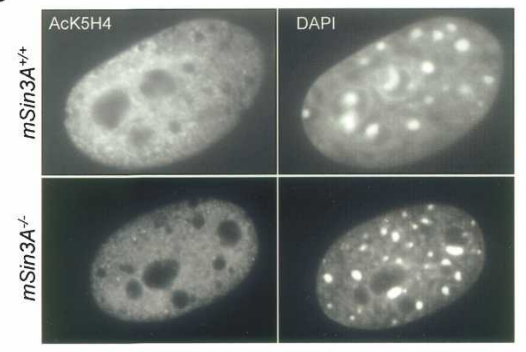

D

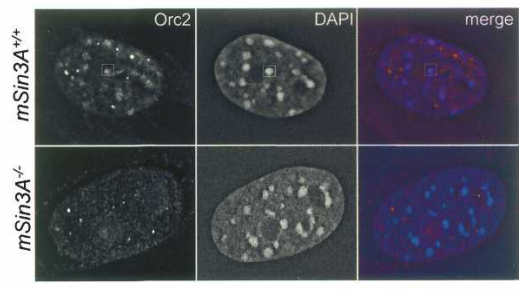

Figure 3. Absence of chromosomal instability despite delocalization of HP1 $\alpha$ and Orc2 in mSin3A-deficient MEFs. (A) Chromosome number in metaphase spreads of MEFs lacking either mSin3A or mSds3. The dashed line indicates a normal murine chromosome count of 40. Analysis of heterochromatin in MEFs lacking mSin3A using immunofluorescence against AcK5H4 (B), HP1 $\alpha$ and tri-meK9H3 $(C)$, and $\operatorname{Orc} 2(D)$.

pathways by means of expression of SV40-Large T Antigen (T-Ag) did not overcome the cell lethal impact of mSin3A deficiency (Supplementary Fig. 3B).

Since primary and transformed cells are known to possess differential responses to HDAC inhibition (for review, see Johnstone and Licht 2003), the essentiality of $\mathrm{mSin} 3 \mathrm{~A}$ was also examined in lymphoma and sarcoma cell lines derived from primary tumors arising in the $m \operatorname{Sin} 3 A^{L /}$

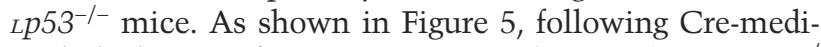
ated depletion of $\mathrm{mSin} 3 \mathrm{~A}$ protein (Fig. $5 \mathrm{~A}$ ), $\mathrm{mSin} 3 \mathrm{~A}^{-/}$ - $p 53^{-/-}$tumor cells, but not $\mathrm{mSin} 3 \mathrm{~A}^{+/+} \mathrm{p} 53^{-/-}$controls, showed strong proliferative arrest (Fig. $5 \mathrm{~B}$ ), a block in DNA replication (Fig. 5C, arrow), and marked apoptosis as indicated by sub- $\mathrm{G}_{1}$ peak and caspase-3 activation (Fig. 5C-E). Together, these data establish that mSin3A serves essential functions in the growth and survival of both primary cells and in cancers derived from hematopoietic and mesenchymal lineages. These genetic and biochemical studies also provide clear evidence that $\mathrm{mSin} 3 \mathrm{~A}$ (and by inference, its associated HDAC activity) participates in the deacetylation of specific lysine residues of p53 under genotoxic stress conditions. Notably, however, the inability of p53 deficiency (or T-Ag expression) to attenuate the adverse cellular impact of $\mathrm{mSin} 3 \mathrm{~A}$ loss of function further indicates that the actions of $\mathrm{mSin} 3 \mathrm{~A}$ extend beyond regulation of p53-p21 $1^{\text {Cip } 1}$ axis and the $\mathrm{Rb}$ family in both primary and transformed mouse cells.

\section{The mSin3A transcriptome}

Since $\mathrm{mSin} 3$ proteins serve integral roles in the regulation of gene expression (Knoepfer and Eisenman 1999) and $\mathrm{mSin} 3 \mathrm{~A}$ loss exerts broad biological effects (this study|, transcriptional profiling and in silico pathway analysis were utilized to understand more precisely these diverse actions of mSin3A. In time course studies, the 4-hydroxytamoxifen (4-OHT)-inducible Cre/Estrogen Receptor $\left(\mathrm{CreER}^{\mathrm{T} 2}\right.$ ) system was used, as it affords tight temporal control of Cre activity in $m \operatorname{Sin} 3 A^{L / L}$ MEFs. As shown in Figure 6A, 4-OHT induction of the CreER ${ }^{\mathrm{T} 2}$-transduced $m \operatorname{Sin} 3 A^{L / L}$ resulted in a cellular phenotype that was similar to that brought about by constitutive Cre retrovirus in $m \operatorname{Sin} 3 A^{L / L}$ MEFs (cf. Fig. 2A), although cell cycle arrest and apoptosis were less pronounced, as observed with cells expressing constitutive Cre-recombinase (Supplementary Fig. 4). On the basis of the kinetics showing steady depletion of $m \operatorname{Sin} 3 A$ mRNA and protein levels (Fig. 6B), a comparative time-course transcriptional profile of CreER ${ }^{\mathrm{T} 2}$-transduced $\mathrm{mSin} 3 \mathrm{~A}^{+/+}$ and $m \operatorname{Sin} 3 A^{L / L}$ MEFs was performed at times $0,24,48$, 72 , and $96 \mathrm{~h}$ following $4-\mathrm{OHT}$ treatment. This approach allows the monitoring of differential gene expression upon $\mathrm{mSin} 3 \mathrm{~A}$ deletion before the onset of the $\mathrm{mSin} 3 \mathrm{~A}$ phenotype, and more readily enables discrimination between direct transcriptional effects due to $\mathrm{mSin} 3 \mathrm{~A}$ ablation versus nonspecific secondary transcriptional changes accompanied by the aggravated cell cycle arrest and apoptosis. dChip software (Li and Wong 2001) was used to analyze the microarray data generated with Affymetrix M430A oligo DNA microarrays.

An Analysis of Variance (ANOVA) procedure was performed to identify genes with nonconstant expression values between the two genetic backgrounds $\left(m \operatorname{Sin} 3 A^{+/+}\right.$ vs. $m \operatorname{Sin} 3 A^{-/-}$. Imposing a $p$-value threshold of $<0.0005$, 
Dannenberg et al.
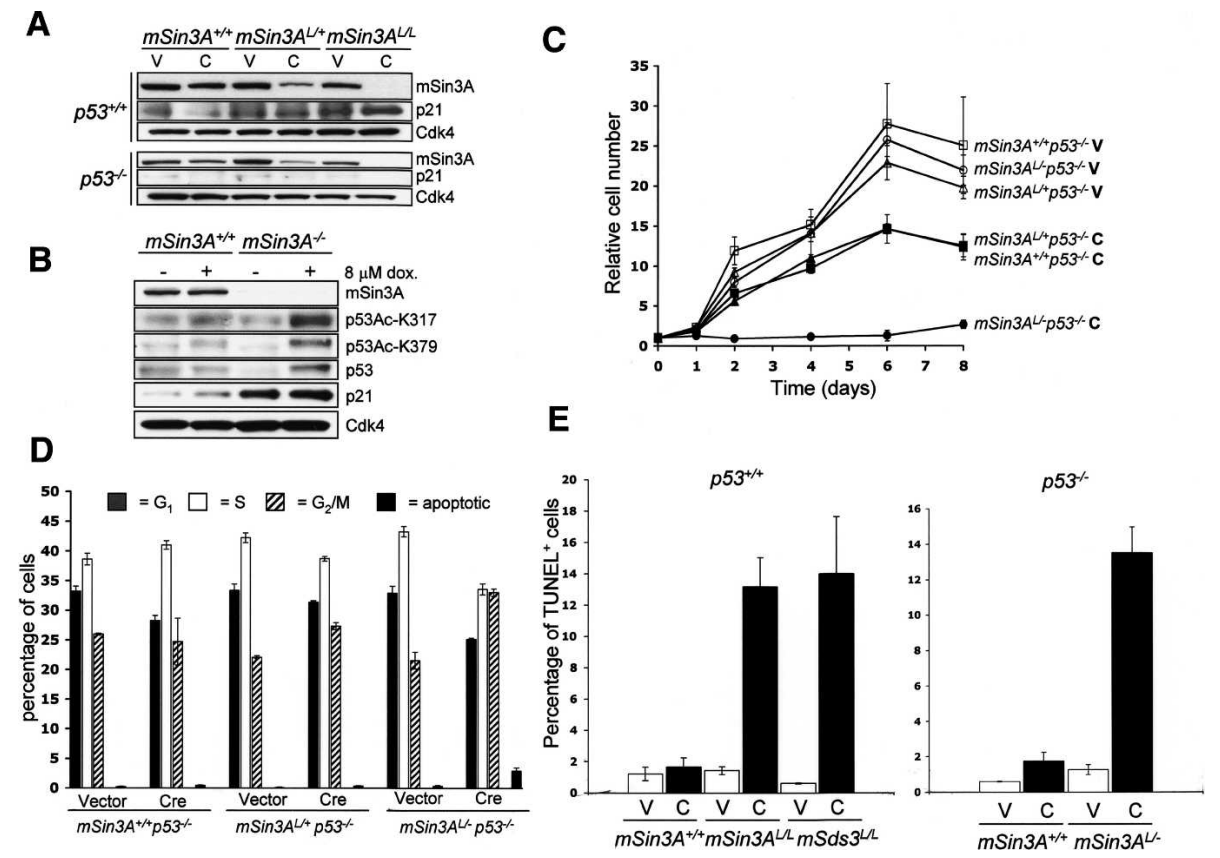

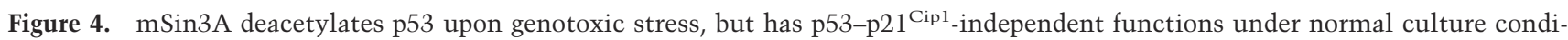
tions. (A) Western blot analysis for mSin3A and $\mathrm{p} 21^{\mathrm{Cip} 1}$ of $m \operatorname{Sin} 3 A^{+/+}, m \operatorname{Sin} 3 A^{L /+}$, and $m \operatorname{Sin} 3 A^{L / L}$ MEFs both in a p53-proficient, as well as a p53-deficient background, infected with either vector-expressing (V) or Cre-recombinase-expressing (C) virus. Cdk4 served as a loading control. $(B)$ Western blot analysis of cell lysates isolated from MEFs with indicated genotypes, expressing Cre-recombinase treated with or without $8 \mu \mathrm{M}$ doxorubicin for $\mathrm{mSin} 3 \mathrm{~A}, \mathrm{p} 53, \mathrm{p} 21^{\mathrm{Cip} 1}$, and acetylated $\mathrm{p} 53^{\mathrm{Lys} 317}$ and $\mathrm{p} 53^{\mathrm{Lys} 379}$. (C) Growth curve analysis of $m \operatorname{Sin} 3 A^{+/+} p 53^{-/-}$(squares), $m \operatorname{Sin} 3 A^{L /+} p 53^{-/-}$(triangles), and $m \operatorname{Sin} 3 A^{L /-} p 53^{-/-}$(circles) MEFs infected with either vector-expressing (open symbols) or Cre-recombinase-expressing (filled symbols) virus under normal culture conditions $(D)$ Percentages of $\mathrm{G}_{1}, \mathrm{~S}, \mathrm{G}_{2} / \mathrm{M}$, and sub- $G_{1}$ (apoptotic) phases in indicated MEF cultures under normal culture conditions. The figure shows a representative of two independent experiments each performed in triplicate. (E) Percentage of apoptotic cells detected by TUNEL-assay in indicated MEFs either in a p53-proficient (left) or p53-deficient (right) background.

1308 genes were determined as having significant nonconstant expression. In concordance with the depletion kinetics of the mSin3A protein, most of these genes showed differential expression starting at $48 \mathrm{~h}$ after addition of 4-OHT. It is worth noting that there were no obvious cellular phenotypes at this 48 -h time point, and thus it is more likely that the observed transcriptional changes are more proximal to $\mathrm{mSin} 3 \mathrm{~A}$ function as opposed to secondary events and terminal cellular collapse (Supplementary Fig. 4). The majority (977) of these differentially expressed genes were up-regulated (Fig. 6C; Supplementary Table 1; Supplementary Information 1,2). A subset of the genes showing altered expression on the Affymetrix expression profiles were verified by real-time RT-PCR analysis on independent generated RNA samples from $m \operatorname{Sin} 3 A^{L / L}$ MEFs expressing Cre-ER ${ }^{\mathrm{T} 2}$ (Fig. 7A). As shown in Figure 7A, whereas $m \operatorname{Sin} 3 A$ RNA levels declined progressively at 48 and $72 \mathrm{~h}$ of 4 -OHT treatment, increased mRNA levels for $m \operatorname{Sin} 3 B$, Mxi1, Sap30, Ing1, Arid4b, Peg3, Set, p130, cyclin E, Odc1, Msh6, Brca1, 53Bp1, Stmn1, and Aldh6a1 were already markedly increased at $48 \mathrm{~h}$, findings consistent with a direct link to $\mathrm{mSin} 3 \mathrm{~A}$ regulation. Correspondingly, ChIP analysis of $m \operatorname{Sin} 3 B, M x i 1$, Ing1, Arid4b, Peg3, Set, p130, Caspase 3, 53Bp, Pmm1, and Aldh6a1 showed that mSin $3 \mathrm{~A}$ physically localizes to the proximal promoters of these genes (Fig. 7B).
Further validation of the corepressor role of $\mathrm{mSin} 3 \mathrm{~A}$ was evident from the up-regulation of several well-established Myc-responsive target genes such as Odc, Cyclin D2, Cyclin E, Nucleolin, Mcm7, Cdc2A, Vamp3, RNA polymerase 1-3 (16 kDa subunit), Fabp5, and Prmt1 among others. In addition to these expected results, there was up-regulation of multiple genes encoding protein products that interact with the $\mathrm{mSin} 3 / \mathrm{HDAC}$ corepressor complex including $m \operatorname{Sin} 3 B, \mathrm{mSds} 3, \mathrm{Hdac2}$, Sap30, and Arid4b (Sap180), Mxi1, Mnt, Prmt5, and Ing1. These findings point to the existence of potential regulatory feedback loops within the mSin3-HDAC pathway, as also indicated by other studies (Lagger et al. 2002; Schuettengruber et al. 2003). Furthermore, we identified three $\mathrm{mSin} 3 \mathrm{~A}$ target genes that are involved in methylation of histones: the arginine protein methyltransferases Prmt1 and Prmt5, and the SET-domain containing methyltransferase Nsd1 (nuclear receptor-binding SET-domain protein 1). Since histone methylation and histone acetylation are closely linked processes (Fischle et al. 2003; Silverstein and Ekwall 2004), these observations prompt speculation that mSin3A may participate in coordinating these processes in part via the transcriptional regulation of these methyltransferaseencoding genes.

Several up-regulated genes functionally cluster as genes involved in $\mathrm{G}_{2} / \mathrm{M}$ transition and cytokinesis in- 
A

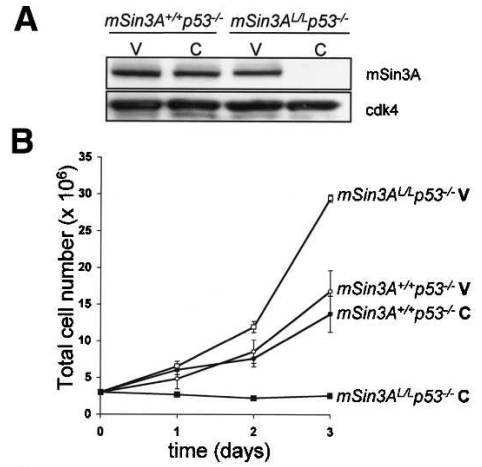

C

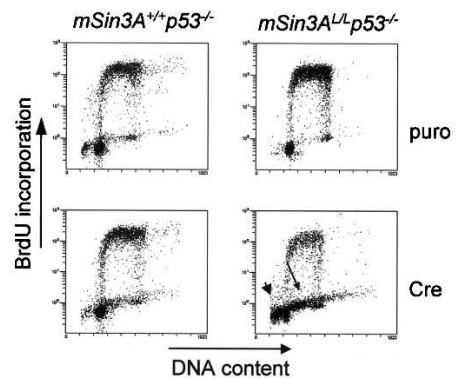

D

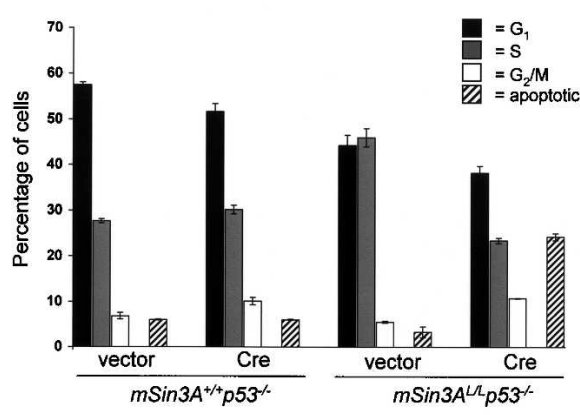

E

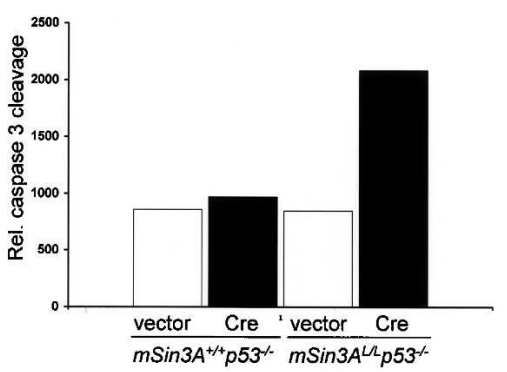

Figure 5. $\mathrm{mSin} 3 \mathrm{~A}$ is required for the survival of tumor cells. (A) Western blot analysis for $\mathrm{mSin} 3 \mathrm{~A}$ of $\mathrm{mSin} 3 \mathrm{~A}^{+/+} \mathrm{p} 53^{-/-}$ and $m \operatorname{Sin} 3 A^{\mathrm{L} / \mathrm{L}} p 53^{-/-}$lymphoma cell lines expressing either vector or Cre-recombinase-expressing viruses. Cdk4 served as a loading control. (B) Growth curve analysis of indicated lymphoma cell lines infected with vector- or Cre-recombinase-expressing viruses. Growth curves were started 3 $\mathrm{d}$ after infection. $(C)$ Cell cycle analysis using BrdU-PI FACS analysis of indicated lymphoma cell lines. Notice the presence of apoptotic cells (arrowhead) and S-phasearrested cells (arrow). (D) Summary of average BrdU-PI FACS analysis of indicated lymphoma cell lines for $G_{1}, S, G_{2} / M$, and sub- $\mathrm{G}_{1}$ (apoptotic) phases of the cell cycle. (E) Caspase-3 activation in $\mathrm{mSin} 3 \mathrm{~A}^{+/}$ $+p 53^{-/-}$and $m \operatorname{Sin} 3 A^{\mathrm{L} / \mathrm{L}} p 53^{-/-}$lymphoma cell lines infected with either vector or Cre-retrovirus. cluding 53Bp1, p130, Gadd45- $\gamma$, Mcm4, Mcm5, Mcm7, Securin, Set, Tacc3, and Cdc2A. None of these genes have been reported to be specifically up-regulated in $G_{2}$ or mitosis, suggesting that their up-regulation is not merely a consequence of the $G_{2} / M$ cell cycle arrest imposed by mSin3A deficiency (Whitfield et al. 2002). Therefore, the fact that some of these genes, when overexpressed, give rise to a $\mathrm{G}_{2} / \mathrm{M}$ arrest (e.g., Gadd45 $\gamma$ and 53Bp1) provides a possible explanation for the observed $\mathrm{G}_{2} / \mathrm{M}$ cell cycle arrest in $\mathrm{mSin} 3 A^{-/-}$cells. Similarly, the apoptosis associated with $\mathrm{mSin} 3 \mathrm{~A}$ depletion could relate in part to transcriptional up-regulation of Caspase-3, Ing1, Peg3, Pdcd5, Trim27, Mcl1, Pin1, and sphingosine phosphate lyase 1, all encoding pro-apoptotic activities (Nicholson et al. 1995; Helbing et al. 1997; Reiss et al. 2004).

Several genes identified in the $\mathrm{mSin} 3 \mathrm{~A}$ transcriptome are known E2F target genes, including Cyclin E, Cyclin D3, Mcm5, Mcm7, Replication Protein A, Rad51, Securin, Ribonucleotide Reductase M1, Ribonucleotide Reductase M2, Caspase 3, cell division cycle 2A, and cell division cycle 6. The changes in E2F target gene regulation are consistent with their regulation by E2F complexes containing retinoblastoma family proteins and class I HDACs (Brehm et al. 1998; Luo et al. 1998; Magnaghi-Jaulin et al. 1998; Lai et al. 2001; Rayman et al. 2002). In a similar manner, the up-regulation of known p53 target genes (Stathmin 1, Fk506bp3) is consistent with documented p53-mSin3A physical and functional interactions (Murphy et al. 1999; Zilfou et al. 2001; this study).

A prominent group of genes present in the $\mathrm{mSin} 3 \mathrm{~A}$ transcriptome participate in DNA-repair processes such as Rpa1, Msh6, Rad17, Lig1, Lig3, Apex1, and Nsep1. These observations are in line with work in yeast sup- porting a role for $\operatorname{Sin} 3$ in the nonhomologous end-joining pathway (Jazayeri et al. 2004). In this regard, there is an up-regulation of several DNA repair genes involved in the homologous recombination pathway including Brca1, 53Bp1, and Rad51. The up-regulation of homologous recombination genes in a context of impaired NHEJ activity raises the intriguing possibility that $\mathrm{mSin} 3 \mathrm{~A}$ may be involved in coordinating the relative levels of NHEJ versus homologous recombination repair activities in the cell.

Consistent with findings in Drosophila, mSin3A deletion resulted in the up-regulation of genes involved in cytosolic and mitochondrial energy-generating pathways (Pdk1, Mrsp23, Oghd, Adac9, Bdh, Got2, Hadh2, Cs, Fxc1, $\operatorname{Prdx} 3$ ), strengthening the provocative role for $\mathrm{mSin} 3 \mathrm{~A}$ in the regulation of mitochondrial respiratory activity (Pile et al. 2003; see below). Finally, mSin3A regulates the expression of several genes involved in DNA replication (Rpa1, Lig1, Mcm4, Mcm5, Mcm7, Nap111) providing a basis for the observed defects in DNA replication upon deletion of $\mathrm{mSin} 3 \mathrm{~A}$, and strengthening the case for a direct role for mSin3A in the DNA replication process.

\section{Identification of known and novel mSin3A transcriptional nodes}

Enrichment of known Myc, E2F, and p53 targets in the $\mathrm{mSin} 3 \mathrm{~A}$ transcriptome prompted us to search the regulatory regions of all genes regulated by $\mathrm{mSin} 3 \mathrm{~A}$ for additional Myc, E2F, and p53 target genes, as well as for unanticipated links other transcription factors and their binding sites. In the case of E2F, $66 \mathrm{mSin} 3 \mathrm{~A}^{-/-}$up-regulated genes contained E2F-binding sites within 500 bp upstream or downstream of the transcriptional start site. 
Dannenberg et al.

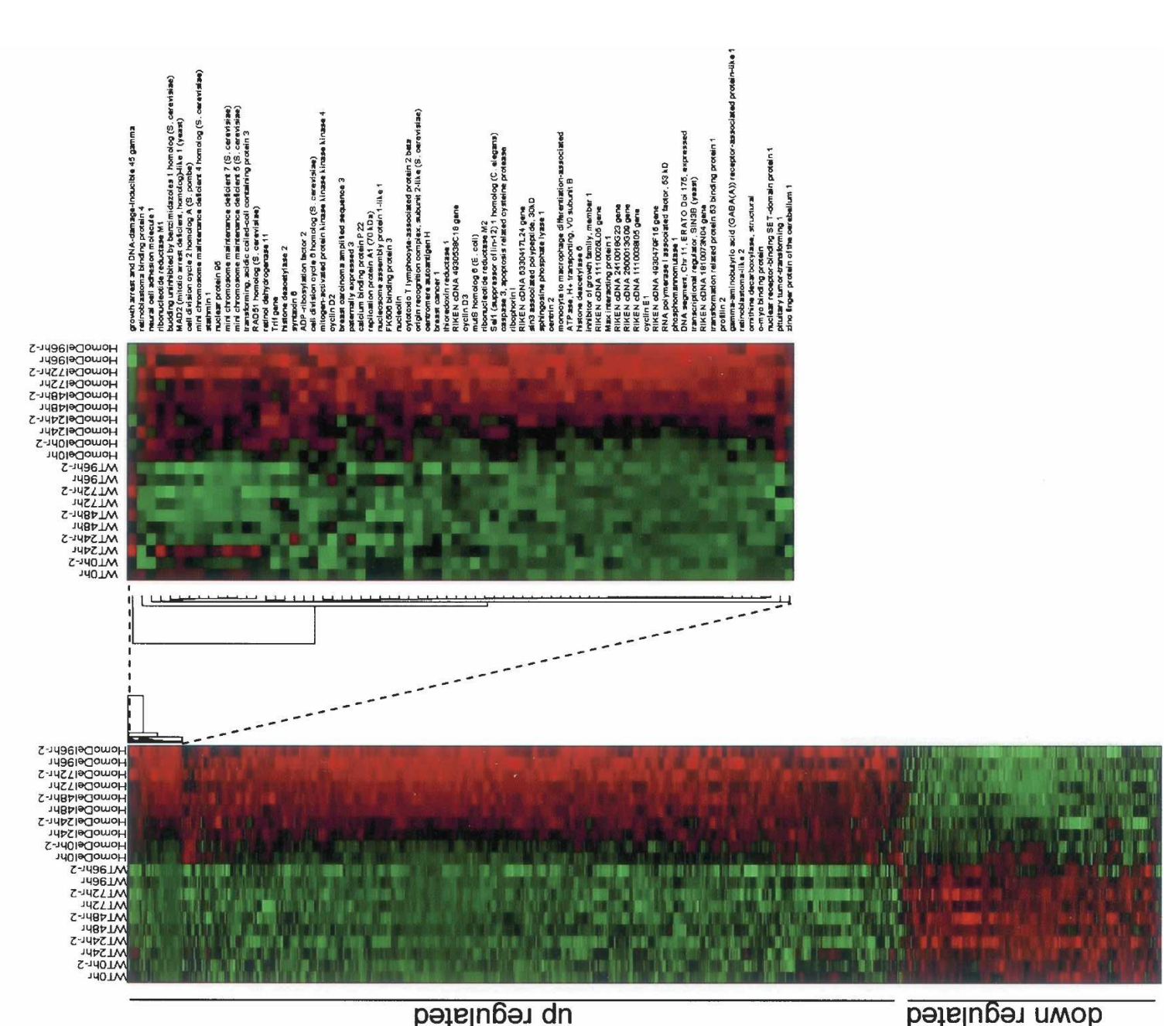

0

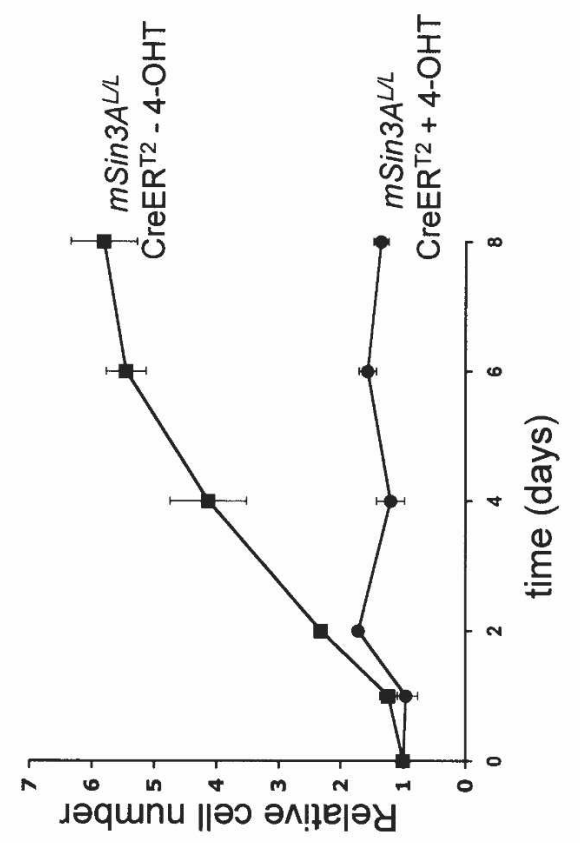

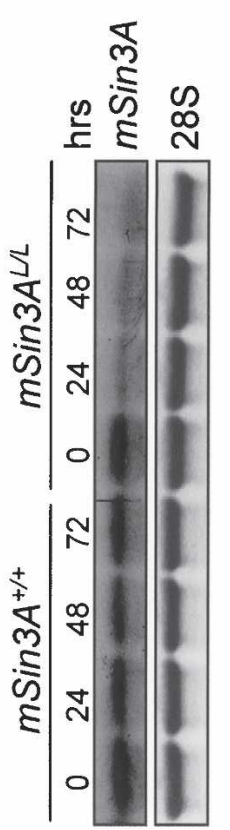

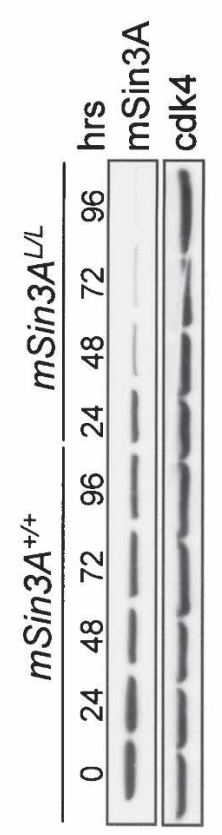

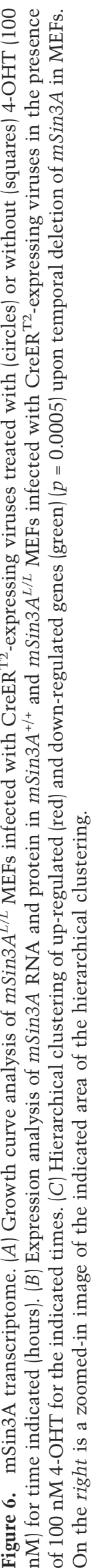


A

C

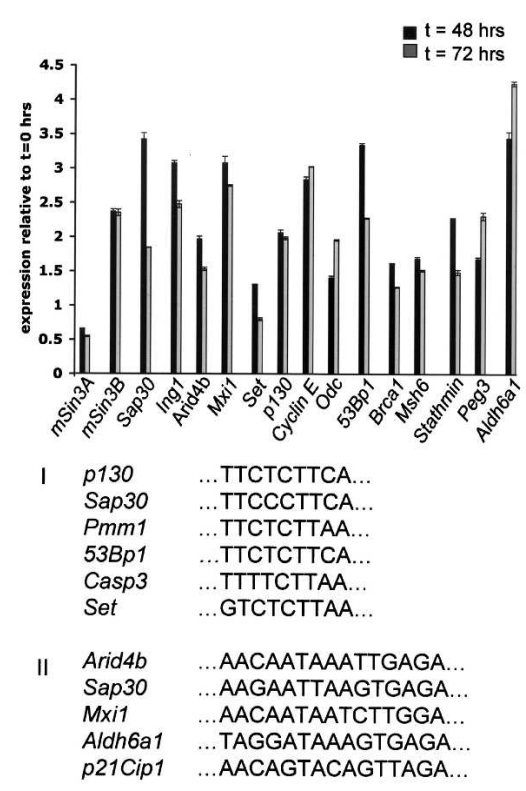

B

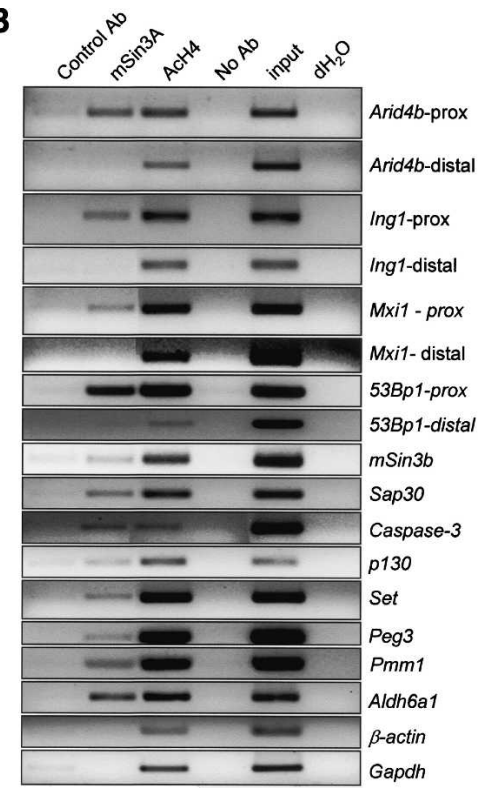

Figure 7. Validated $\mathrm{mSin} 3 \mathrm{~A}$ target genes reveal novel $\mathrm{mSin} 3 \mathrm{~A}$-associated cis-regulatory elements. (A) RNA expression levels of $m \operatorname{Sin} 3 A$ and $\mathrm{mSin} 3 \mathrm{~A}$ target genes determined by real-time RT-PCR in $m \operatorname{Sin} 3 A^{L / L}$ MEFs infected with $\mathrm{CreER}^{\mathrm{T} 2}$-expressing viruses, 48 and $72 \mathrm{~h}$ after addition of $100 \mathrm{nM}$ 4-OHT relative to RNA levels at $0 \mathrm{~h}$ after tamoxifen addition. (B) Identification of $\mathrm{mSin} 3 \mathrm{~A}$ on promoters of indicated $\mathrm{mSin} 3 \mathrm{~A}$ target genes by ChIP using antibodies against SV40 Large T (negative control), mSin3A, and acetylated $\mathrm{H} 4$ (positive control). Whereas $\mathrm{mSin} 3 \mathrm{~A}$ cannot be found on the distal parts of the mSin3a target genes Arid4b, Mxi1, Ing1, and 53Bp1 nor on promoters of two non-mSin3A targets $(\beta-a c$ tin and Gapdh), mSin3A is located on proximal promoter parts of indicated genes. $(C)$ DNA sequence motifs for binding of Stat transcriptional regulators (I) and the nucleosome remodeling factor Falz (II) could be found in a subset of $\mathrm{mSin} 3 \mathrm{~A}$ target genes.
Compared with a random collection of 1161 genes, there was a 1.95 -fold enrichment $(4.40 \%$ vs. $8.61 \% ; p=0.044)$ in E2F-binding sites in the collection of induced genes upon deletion of $\mathrm{mSin} 3 \mathrm{~A}$. Scanning for p53-binding elements (which are typically positioned at greater distances from the transcriptional start site), $64 \mathrm{mSin} 3 \mathrm{~A}^{-/-}$ up-regulated genes were found to contain p53-binding sites within 5000 bp of the transcriptional start site in either upstream or downstream direction. A 1.85-fold enrichment was observed for p53-binding sites in the $\mathrm{mSin} 3 A^{-/-}$up-regulated genes compared with the random genes $(8.47 \%$ vs. $4.57 \%, p=0.046)$. Finally, a search for Myc target genes by scanning the promoters of the up-regulated genes for E-box sequences identified 189 genes and 1.34 -fold enrichment $(24.6 \%$ vs. $18.33 \%$, $p=0.183$ ) for E-box sequences over a set of random genes. The relatively low enrichment for E-box sequences is likely due to the reduced information present in E-box sequences compared with the longer E2F- and p53-binding sequences, as well as the known ability of the Myc oncoprotein to regulate a significant fraction of the genome, as revealed by studies in human and Drosophila (Fernandez et al. 2003; Orian et al. 2003). Together, these findings show that gene expression profiling and in silico promoter analysis can lead to the identification of E2F-, Myc-, and p53-responsive targets.

Next, we sought to validate further the above links between $\mathrm{mSin} 3 \mathrm{~A}$ and the $\mathrm{E} 2 \mathrm{~F}, \mathrm{Myc}$, and p53 transcriptional networks, and to search for new $\mathrm{mSin} 3 \mathrm{~A}$ interactions. Additionally, since $\mathrm{mSin} 3 \mathrm{~A}$ does not directly bind to DNA, we sought to identify DNA-binding transcription factors like E2F, Myc, and p53 that are used by $\mathrm{mSin} 3 \mathrm{~A}$ to regulate gene expression. To this end, a knowledge-based database (Ingenuity Pathways Knowledge Base, http://www.ingenuity.com) was used to integrate the $\mathrm{mSin} 3 \mathrm{~A}$ transcriptome (particularly the upregulated genes) into various pathways. As expected, this network analysis identified the transcription factors E2F1, E2F4, Myc, and p53 as nodal points that connect numerous mSin3A-modulated genes (Supplementary Fig. 5), thus providing a measure of validation for the cis-regulatory element results above. In addition to these anticipated networks, several other networks emerged, including those governed by the nodal transcription factors Fos and peroxisome proliferative activated receptor (PPAR). The latter transcription factor is of special interest, since the mSin3A transcriptome contains many genes involved in mitochondrial metabolism/respiration (Acs11, Nr2f2, Ctps, Pmm1, Tpm2, Pc, Scarb1, Hsd17b4, Cs, Fabp5, and Umpk among others) (see Supplementary Table 1; Supplementary Fig. 6), and the PPAR pathway has been implicated in mitochondrial respiration and metabolism (Puigserver et al. 1998). Furthermore, regulation of gene expression through the PPAR pathway appears subject to regulation by histone deacetylation (Fan et al. 2004). Similarly, Fos protein heterodimerizes with Jun, which has been shown to repress transcription by recruiting $\mathrm{mSin} 3 \mathrm{~A} / \mathrm{HDAC}$ complex (Lee et al. 2000). Finally, the Pathway Knowledge Base also revealed links to various genes involved in DNA repair, reinforcing the data from yeast of a role for the otholog in DNA repair (Supplementary Fig. 6; Jazayeri et al. 2004).

Next, we conducted an unbiased search for cis-elements that are overrepresented in the promoters of validated mSin3A target genes: $m \operatorname{Sin} 3 B, M x i 1$, Ing1, Arid4b, Sap30, 53Bp1, Peg3, Set, Caspase 3, p130, and Aldh6a1 (i.e., genes confirmed by ChIP analysis and real-time RTPCR) (Fig. 7A,B). DNA sequences spanning 500 bp on each side of the mSin3A ChIP-positive genome fragment were overlaid across genomes of multiple species to identify conserved regions (Siepel and Hauser 2005). These conserved regions were subsequently analyzed for DNA-binding motifs using the MEME motif-finding program (Bailey and Elkan 1994) and compared with known 
transcription factor-binding motifs using the Match Program in Transfac (Matys et al. 2003). As shown in Figure 7C, two cis-regulatory elements were identified that are similar to DNA-binding motifs for the transcriptional activator Stat, whose DNA-binding activity has been shown to be acetylation dependent (Wang et al. 2005; Yuan et al. 2005) and Falz (also know as FAC1/BPTF/ Nurf301), a nucleosome remodeling factor that is used in the ISWI ATP-dependent chromatin remodeling complex NURF (Bowser et al. 1995; Jordan-Sciutto et al. 1999; Jones et al. 2000; Xiao et al. 2001; Badenhorst et al. 2002). Together, these data suggest that the combined computational and ChIP analyses provides a means for the validation of known $\mathrm{mSin} 3 \mathrm{~A}$ cofactors and an entry point for the identification of novel $\mathrm{mSin} 3 \mathrm{~A}$ cofactors.

\section{Discussion}

This study provides genetic evidence that mSin3A plays a critical role in the regulation of several prominent transcriptional networks and is essential for the proliferation and survival of both normal and neoplastic cells. Consistent with roles for $\mathrm{mSin} 3 \mathrm{~A}$ in diverse physiological processes, loss of $\mathrm{mSin} 3 \mathrm{~A}$ function provokes an early embryonic lethal condition, generates defects at all phases of the cell cycle including the DNA synthesis phase, enhances apoptotic responses, particularly in the setting of genotoxic stress, and alters the expression of many genes linked to cell cycle regulation, DNA replication, DNA repair, mitochondrial metabolism, and histone modification. Consistent with antecedent biochemical data, computational analysis of the mSin $3 \mathrm{~A}$ transcriptome and the promoter regions of up-regulated genes provided genetic confirmation of the critical role of $\mathrm{mSin} 3 \mathrm{~A}$ in the regulation of the Myc-Mad network, the pRB-E2F axis, and the p53 pathway. In addition, our computational efforts have also forged putative links to gene networks regulated by PPAR, FOS, STAT, and FALZ.

Despite up-regulation of mSin3A partners, as well as ubiquitous coexpression of the highly related $\mathrm{mSin} 3 \mathrm{~B}$ homolog, the loss of mSin $3 \mathrm{~A}$ function exacted profound physiological consequences, underscoring the essential and separable roles of the mSin 3 homologs. That $\mathrm{mSin} 3 \mathrm{~A}$ and $\mathrm{mSin} 3 \mathrm{~B}$ possess nonoverlapping functions is in line with the capacity of $\mathrm{mSin} 3 \mathrm{~A}$ and $\mathrm{mSin} 3 \mathrm{~B}$ to occupy different promoters in mammalian cells (Rayman et al. 2002), as well as the assignment of distinct functions for the two yeast Sin3 orthologs (Nakayama et al. 2003; Silverstein et al. 2003). The nature and extent of the common and distinct functions of $\mathrm{mSin} 3 \mathrm{~A}$ and $\mathrm{mSin} 3 \mathrm{~B}$ will require additional direct genetic study. Along these lines, it will be paramount to determine whether there is either functional redundancy among $\mathrm{mSin} 3 \mathrm{~A}$ and $\mathrm{mSin} 3 \mathrm{~B}$ in the establishment of functional centromeric heterochromatin, or whether there is indeed a unique $\mathrm{mSin} 3 \mathrm{~A} / \mathrm{B}$-independent function for $\mathrm{mSds} 3$ in this aspect of chromosome biology.

At the same time, although mSds 3 appears to be critical for maintenance of HDAC-associated enzymatic ac- tivity in the mSin3A and $\mathrm{mSin} 3 \mathrm{~B}$ corepressor complex (Alland et al. 2002), it is important to note that mSin $3 A^{-/-}$cells exhibit phenotypes that are not observed in the $\mathrm{mSds}^{-/-}$cells. Specifically, $\mathrm{mSin} 3 \mathrm{~A}^{-/-}$ MEF cultures harbor a subpopulation containing S-phase DNA content with no ongoing DNA replication (no BrdU incorporation). Given that this DNA content anomaly cannot be attributed to chromosomal instability and that there is prominent representation of DNA replication genes in the $\mathrm{mSin} 3 \mathrm{~A}$ transcriptome, we propose that $\mathrm{mSin} 3 \mathrm{~A}$ plays a direct role in regulation of DNA replication in mammalian cells. This hypothesis is in line with previous studies in S. cerevisiae, showing a role for Sin3 and Rpd3 (ortholog of HDAC1) in the activation of late origins of replication independent relating to their role in transcriptional repression (Aparicio et al. 2004). Additionally, in Drosophila, activation of origin of replication is dependent on $\mathrm{Rpd} 3$ as evidenced by the loss of $R p d 3$ function, resulting in genome-wide hyperacetylation, genomic replication, and redistribution of the origin binding protein ORC2 (Aggarwal and Calvi 2004). Together, these collective insights have shaped our view of the mSin 3 corepressor complex. Rather than the existence of a monolithic collection of components, the data are consistent with the ability of the $\mathrm{mSin} 3$ complex to operate in a more modular fashion, such that various transcription factors and other DNA-binding elements may recruit only a subset of the mSin3/HDAC components. This speculation is consistent with emerging observation of the existence of several biochemically distinct forms of the $\mathrm{mSin} 3$ multiprotein complex (Fleischer et al. 2003).

In the context of cancer, a strong consensus has emerged that modulators of chromatin architecture are intimately linked to key cancer-relevant pathways. Particularly relevant to this issue is the previously documented physical and biochemical interactions between the mSin3A corepressor and the p53 tumor suppressor. Here, our genetic analysis has substantiated the ability of $\mathrm{mSin} 3 \mathrm{~A}$ to modulate p53 activation in the setting of DNA damage, as evidenced by Lys 317 and Lys 379 hyperacetylation and increased p53 protein levels upon loss of $\mathrm{mSin} 3 \mathrm{~A}$ function. Thus, we propose that an important function of the $\mathrm{mSin} 3 \mathrm{~A} / \mathrm{HDAC}$ complex is the regulation of p53 acetylation status and cell cycle control following genotoxin-induced injury. In addition, it is worth noting that several deacetylases and HDAC-containing complexes have shown the capacity to deacetylate p53, including the NuRD complex (Luo et al. 2000), all Class I HDACs (Juan et al. 2000), and the class III deacetylase SIRT1 (Luo et al. 2001; Vaziri et al. 2001; Cheng et al. 2003). These observations, together with the findings of this report, raise the interesting possibility that multiple protein complexes, and therefore, multiple biochemical signaling pathways, converge on the p53 protein to regulate its activity via acetylation in various physiological settings.

In silico promoter scanning revealed significant enrichment of Myc, E2F, and p53 cis-elements in the $\mathrm{mSin} 3 \mathrm{~A}$ transcriptome. It is interesting to note, how- 
ever, that not all Myc, E2F, and p53 target genes are up-regulated, which implies that mSin3A might regulate only a subset of these targets, that mSin $3 \mathrm{~A}$ may only engage these transcription factors under certain physiological conditions or cell types, and/or that $\mathrm{mSin} 3 \mathrm{~B}$ may serve overlapping functions on a subset of these gene targets. One important caveat to these suppositions is the fact that only a limited region of the promoter sequences of the mSin $3 \mathrm{~A}$ transcriptome genes was scanned, and it is possible that Myc, E2F, and p53 cisregulatory elements were not captured in our analyses, thereby resulting in an underestimation of the $\mathrm{mSin} 3 \mathrm{~A}$ target genes coregulated by Myc, p53, and E2F. The identification of the Stat and Falz cis-regulatory elements in a subset of the $\mathrm{mSin} 3 \mathrm{~A}$ target genes shows that $\mathrm{mSin} 3 \mathrm{~A}$ uses various DNA-binding transcription factors to confer selectivity and specificity in transcriptional regulation. Recently, it was shown that acetylation of Stat3 is critical for the protein to form stable dimers required for cytokine-stimulated DNA-binding and transcriptional regulation and to enhance transcription of cell growthrelated genes (Wang et al. 2005; Yuan et al. 2005). These studies, together with our finding that $\mathrm{mSin} 3 \mathrm{~A}$ can repress Stat target gene transcription, suggests a model in which mSin3A-associated HDAC activity inhibits Stat3 dimerization and neutralizes its transcriptional potential. Various studies have implied collaborative interactions between different chromatin remodeling complexes, including $\mathrm{mSin} 3 \mathrm{~A} / \mathrm{HDAC}$ and SWI/SNF (Sternberg et al. 1987; Sif et al. 2001; Kuzmichev et al. 2002). In this context, our finding that $\mathrm{mSin} 3 \mathrm{~A}$ regulates gene transcription through Falz appears relevant, as Falz is a component of the ISWI ATP-dependent nucleosome remodeling complex NURF. Falz contains a bromodomain, which are known to bind acetylated lysines in histones and nonhistone proteins (for review, see Yang 2004), suggesting that Falz might recruit $\mathrm{mSin} 3 \mathrm{~A} / \mathrm{HDAC}$ complexes to such targets to deacetylate specific promoter regions or modify the transcriptional activity of nonhistone proteins. A human NURF complex was shown to contain, beside FALZ, also RbAp46 and RbAp48, two proteins that are often found in complex with $\mathrm{mSin} 3 \mathrm{~A}$ (Barak et al. 2003). Notably, Nurf301 can act as a negative regulator of the JAK/STAT signaling pathway, downstream of the STAT proteins, suggesting that mSin3A may regulate gene transcription through both DNA-binding transcription factors (Badenhorst et al. 2002). Along these lines, our computational and ChIP analyses reveal that the mSin3A target gene Sap30 contains Stat- as well as Falz-binding motifs in its promoter.

In summary, the integrated genetic, biochemical, and computational approaches of this study has enabled us to gain insight into the diverse functions of $\mathrm{mSin} 3 \mathrm{~A}$. The application of this integrated approach and conditional somatic inactivation may find utility in the analysis of multifunctional complexes serving cell essential functions. In the case of $\mathrm{mSin} 3 \mathrm{~A}$, this study confirmed the essential role of $\mathrm{mSin} 3 \mathrm{~A}$, and by extension, the $\mathrm{mSin} 3 \mathrm{~A}$ corepressor complex in numerous biological processes relevant to normal physiology and to cancer, and served to uncover known and novel cofactors regulating various biochemical processes (e.g., DNA replication, nuclesomal remodeling, etc.).

The observations of this report suggest a general strategy for assessment of the other components of the mSin 3 corepressor complex in normal cells and in cancer.

\section{Materials and methods}

\section{Generation of $\mathrm{mSin} 3 \mathrm{~A}$ conditional null allele}

A conditional $m$ Sin3A-targeting construct was generated by flanking $m S i n 3 A$ exon 4 with a 5 ' loxP-Frt-PGK-neomcyin expression cassette (Aguirre et al. 2003) and a 3' loxP site. Upon electroporation of 129/SvOla embryonic stem (ES) cells and selection at $200 \mu \mathrm{g} / \mathrm{mL}$ G418, homologous recombinants were identified by Southern blot analysis. Correctly targeted ES clones were injected into $\mathrm{C} 57 \mathrm{Bl} / 6$ blastocysts and germline transmitting chimeric mice were bred to CAGG-Flpe (Rodriguez et al. 2000) and EIIa-Cre transgenic mice (Lakso et al. 1996) to generate the $m \operatorname{Sin} 3 A^{L}$ and $m \operatorname{Sin} 3 A^{-}$alleles, respectively. Mice were genotyped by Southern analysis and multiplex PCR (primers and conditions are available upon request).

\section{Preparation of MEFs, cell culture, and retroviral infection}

MEFs were isolated from 13.5-d-post-coitum (dpc) embryos using standard procedures (Dannenberg et al. 2000) and cultured in DMEM supplemented with $10 \%$ fetal bovine serum (FBS), 0.1 $\mathrm{mM} \beta$-mercapto-ethanol, and antibiotics. Ecotropic retroviral supernatants were produced by cotransfection of $293 \mathrm{~T}$ packaging cells with $6 \mu \mathrm{g}$ viral DNA and $6 \mu \mathrm{g}$ pCL vector (Naviaux et al. 1996) using lipofectamin 2000 (Invitrogen) according to the manufacturer's instructions. Viral supernatant was collected and filtered through a $0.45-\mu \mathrm{m}$ filter 48,56 , and $72 \mathrm{~h}$ post-transfection. Low-density cultures of early passage MEFs were infected two times for at least $6 \mathrm{~h}$ with viral supernatants containing $4 \mu \mathrm{g} / \mathrm{mL}$ polybrene (Sigma) with an 8 -h interval. After a recovery period of $36 \mathrm{~h}$, the MEFs were selected for at least $48 \mathrm{~h}$ using medium containing $2.5 \mu \mathrm{g} / \mathrm{mL}$ puromycin (Sigma) before the cells were subjected to any of the analyses reported in this study.

To study p53 acetylation, MEFs were infected with either control or Cre-expressing viruses and treated with doxorubicin $72 \mathrm{~h}$ post-infection and processed as described in Cheng et al. (2003).

Proliferation curves, cell cycle, and apoptosis analyses

Proliferation curves were carried out as described in Dannenberg et al. (2000). Cell cycle analysis was performed by incubating MEFs on 10-cm tissue culture plates with $10 \mu \mathrm{M} 5$-Bromodeoxy uridine (Sigma) for $1 \mathrm{~h}$ and processed as described in Dannenberg et al. (2000). Assessment of apoptosis was performed by growing MEFs on eight-well chamber slides for 24-48 $\mathrm{h}$, and subsequently analyzed using an In Situ Cell Detection Kit (Roche) according to the manufacturer's instructions. Quantification of apoptotic cells was performed by counting the number of TUNEL-positive nuclei in 100 DAPI-stained nuclei in three different fields at $100 \times$ magnification. All experiments were performed at 5-7 d after retroviral infection with pBabepuro or pBabe-Cre virus.

\section{Metaphase spreads and immunofluoresence}

Metaphase spreads from MEFs were generated as described in David et al. (2003). Immunofluoresence analysis of MEFs was 
performed 5-7 d after retroviral infection with pBabe-puro or pBabe-Cre virus. MEFs were cultured for $24-48$ h on eight-well chamber slides, fixed with $2 \%$ fresh paraformaldehyde (Pierce) and permeabilized with $0.1 \%$ Triton X-100. Antibodies against the following proteins were used: AcK12H4, AcK5H4, meK9H3, meK20H4 (Upstate), HP1 $\alpha$ (Chemicon). For the Orc2 (BD Biosciences)-staining, Triton extraction was performed prior to fixation as described in Prasanth et al. (2004). Immunofluorescent images were acquired using either a Zeiss Axiovert 200-M inverted microscope or a CoolSnap HQ CCD camera (Photometrics) driven by the Slidebook 4.0 b 2.5 software (intelligent Imaging Innovations). Pictures were acquired with $1 \times 1$ binning and a $0.1-\mathrm{mm}$ Z-step. Deconvolution was performed by the nearest neighbor method with 20 iterations.

\section{Protein analyses}

Protein levels were determined by Western blot analyses using routine protocols. Antibodies against $\mathrm{mSin} 3 \mathrm{~A}(\mathrm{~K}-20), \mathrm{mSin} 3 \mathrm{~B}$ (AK-12), p130 (C-20), Cdk4 (C-22), and p21 ${ }^{\mathrm{Cip} 1}$ (C-19) were obtained from Santa Cruz, HDAC1 from Upstate, p53 antibody (Ab-7) from Oncogene Science, and p53AcK317 and p53AcK379 from Trevigen. Peroxidase-conjugated goat anti-rabbit and goat anti-mouse secondary antibodies were from Pierce. To detect anti-p53 antibodies, we used peroxidase-conjugated bovine antisheep antibodies from Santa Cruz.

Generation and culturing of $\mathrm{mSin} 3 \mathrm{~A}^{\mathrm{L} / \mathrm{L}} \mathrm{p} 53^{-/-}$sarcomas and lymphomas

$\mathrm{mSin} 3 A^{+/+} p 53^{-/-}$and $\mathrm{mSin} 3 A^{L / L} \mathrm{p} 53^{-/-}$mice were generated by $m \operatorname{Sin} 3 A^{L /+} p 53^{-/-}$intercrosses, and subsequently allowed to age. On average, at 10-15 wk of age, these mice developed (angio)sarcoma and T-cell lymphomas. Single-cell suspensions of sarcomas and lymphomas were prepared and taken into culture. Sarcomas were maintained in culture using exactly the same conditions as for MEFs. Lymphomas were cultured in culture flasks in RPMI medium (Gibco), supplemented with 10\% FBS, $0.1 \mathrm{mM} \beta$-mercapto ethanol, and antibiotics.

\section{Gene expression profiling}

Subconfluent $m \operatorname{Sin} 3 A^{+/+}$and $m \operatorname{Sin} 3 A^{L / L}$ MEFs cultures on 10$\mathrm{cm}$ culture dishes were twice infected with retroviruses expressing the CreER ${ }^{\mathrm{T} 2}$ recombinase and selected for puromycin $(2.5 \mu \mathrm{g} / \mathrm{mL})$ for the rest of the experiment. After reaching confluency, the cells were passaged onto $15-\mathrm{cm}$ culture dishes and selected for an additional $2 \mathrm{~d}$. Subsequently, each plate was split into $5 \times 310-\mathrm{cm}$ culture dishes. For five consecutive days, 4-hydroxy tamoxifen was added to a new set of three $10-\mathrm{cm}$ dishes at a final concentration of $100 \mathrm{mM}$. RNA and protein were isolated at the end of the experiment to document $\mathrm{mSin} 3 \mathrm{~A}$ status. Two $10-\mathrm{cm}$ plates for each time point were used to isolate RNA using Trizol (Invitrogen) and an RNeasy mini kit (Qiagen). Gene expression profiling was performed on the Affymetrix M430A platform.

\section{Real time RT-PCR}

Real-time PCR was performed using the Quantitec SYBR kit from Qiagen according to the manufacturer's prescription. Primer sequences are available on request. RNA was isolated from $m \operatorname{Sin} 3 A^{L / L}$ MEFs expressing CreER ${ }^{\mathrm{T} 2}$ and treated with Tamoxifen for either 0, 48, or $72 \mathrm{~h}$ using Rneasy kits (Qiagen). To calculate RNA quantities, we established standard curves with serial dilutions of known RNA concentrations. One-hun- dred nanograms of total RNA was used for each RT-PCR /Qiagen). All RT-PCRs were performed in triplicate.

\section{ChIP and identification of cis-regulatory elements}

ChIP experiments were performed using confluent early passage (passage 4) primary MEFs (pMEFs). For each ChIP assay, we used $3 \times 10^{7}$ cells and followed a published protocol (Ren et al. 2002). Antibodies used for ChIP are anti-mSin3A (K-20; Santa Cruz), anti-SV40 LargeT (gift of J. DeCaprio, Dana-Farber Cancer Institute, Boston, MA), anti-acetylated histone H4 (Upstate). PCR primers were designed for each kilobase of a 5 -kb promoter fragment, and are available on request. Information on the methodology used in the identification of novel cis-regulatory elements in promoters of $\mathrm{mSin} 3 \mathrm{~A}$ target genes can be found in the Supplemental Material.

\section{Bioinformatic analyses of the gene expression profiling data}

Analysis of the raw gene expression profiling was performed using dChip software (Li and Wong 2001). In order to identify potential E2f-binding, sites in the promoters of 1182 probe sets that showed significant ( $p=0.0005)$ up-regulation upon mSin3A deletion, we mapped the genes onto the genome and determined the transcriptional start site (TSS). Promoters as large as $500 \mathrm{bp}$ upstream and $500 \mathrm{bp}$ down stream of the TSS were scanned with a known E2F matrix for potential E2f-binding sites. Only the two best hits per promoter were recorded for location and score. p53-binding sites in the same promoters were found by following the same procedure, except that the scan region for the p53 matrix was expanded to $5000 \mathrm{bp}$ upstream and $5000 \mathrm{bp}$ down stream of the TSS. E-box sequences were identified in a region spanning $1000 \mathrm{bp}$ upstream and $200 \mathrm{bp}$ downstream of the TSS. Sequences for the E2F, p53, Myc, and AP-1-binding sites used to scan the promoter regions of the genes in the mSin3A transcriptome are documented in Transfac (Matys et al. 2003). To identify gene networks within the mSin3A transcriptome, we used the Ingenuity Pathways Knowledge Base (http://www.ingenuity. com).

\section{Acknowledgments}

We are grateful to James Horner and Michelle Neptune of the transgenic and gene-targeting facility for generating the targeted ES cells and the germline mouse strains. We acknowledge Yao Yao for advice on the use of recombineering to generate the targeting construct. We are thankful for the expert assistance of the animal facility staff; Shan Jiang, Karen Marmon, Alice Yu, and Yan Zhang. We thank Pedro Carvalho for assistance with deconvolution microscopy. We thank Erguen Sahin, Giovanni Tonon, and Ruben Carrasco for helpful discussions. We thank Nabeel El-Bardeesy for the Cre- and Cre-ER ${ }^{\mathrm{T} 2}$ retroviral vectors. We thank Giovanni Tonon for assistance with the Ingenuity Pathways Knowledge Base analysis. We thank Alex Stegh for help in the analysis of caspase-3 activity. We thank Omar Kabbarah for help with the real-time RT-PCR. We thank Ruben Carrasco for expert histological examination of tissue slides. We thank J. DeCaprio for kindly providing the SV40 Large T antibody and Darrell Borger for the retroviral Large T SV40 expression construct. We are grateful to Robert N. Eisenman for communicating data prior to publication. J-H.D. was a Damon-Runyon Fellow supported by the Damon Runyon Cancer Research Foundation and is currently a Dutch Cancer Society Fellow. This work was funded by the National Institutes of Health grants GM67250 (W.H.W. and S.Z.) and RO1CA86379 (R.A.D.) 
and by grants from the American Cancer Society. R.A.D. is an American Cancer Society Research Professor and an Ellison Senior Scholar.

\section{Note added in proof}

A study by Cowley et al. (2005) using an independently generated $m \operatorname{Sin} 3 A$ conditional mouse shows similar effects of $\mathrm{mSin} 3 \mathrm{~A}$ deficiency on embryonic development, MEF proliferation, and chromosomal dynamics.

\section{References}

Aggarwal, B.D. and Calvi, B.R. 2004. Chromatin regulates origin activity in Drosophila follicle cells. Nature 430: 372-376.

Aguirre, A.J., Bardeesy, N., Sinha, M., Lopez, L., Tuveson, D.A., Horner, J., Redston, M.S., and DePinho, R.A. 2003. Activated Kras and Ink4a/Arf deficiency cooperate to produce metastatic pancreatic ductal adenocarcinoma. Genes \& Dev. 17: 3112-3126.

Alland, L., David, G., Shen-Li, H., Potes, J., Muhle, R., Lee, H.C., Hou, H.J., Chen, K., and DePinho, R.A. 2002. Identification of mammalian Sds3 as an integral component of the Sin3/ histone deacetylase corepressor complex. Mol. Cell. Biol. 22: $2743-2750$.

Aparicio, J.G., Viggiani, C.J., Gibson, D.G., and Aparicio, O.M. 2004. The Rpd3-Sin3 histone deacetylase regulates replication timing and enables intra-S origin control in Saccharomyces cerevisiae. Mol. Cell. Biol. 24: 4769-4780.

Ayer, D.E. 1999. Histone deacetylases: Transcriptional repression with siners and nurds. Trends Cell. Biol. 9: 193-198.

Ayer, D.E., Lawrence, Q.A., and Eisenman, R.N. 1995. MadMax transcriptional repression is mediated by ternary complex formation with mammalian homologs of yeast repressor Sin3 Cell 80: 767-776.

Badenhorst, P., Voas, M., Rebay, I., and Wu, C. 2002. Biological functions of the ISWI chromatin remodeling complex NURF. Genes \& Dev. 16: 3186-3198.

Bailey, T.L. and Elkan, C. 1994. Fitting a mixture model by expectation maximization to discover motifs in biopolymers. Proc. Int. Conf. Intell. Syst. Mol. Biol. 2: 28-36.

Barak, O., Lazzaro, M.A., Lane, W.S., Speicher, D.W., Picketts, D.J., and Shiekhattar, R. 2003. Isolation of human NURF: A regulator of Engrailed gene expression. EMBO J. 22: 60896100.

Bowser, R., Giambrone, A., and Davies, P. 1995. FAC1, a novel gene identified with the monoclonal antibody Alz50, is developmentally regulated in human brain. Dev. Neurosci. 17: 20-37.

Brehm, A., Miska, E.A., McCance, D.J., Reid, J.L., Bannister, A.J., and Kouzarides, T. 1998. Retinoblastoma protein recruits histone deacetylase to repress transcription. Nature 391: 597-601.

Cheng, H.L., Mostoslavsky, R., Saito, S., Manis, J.P., Gu, Y., Patel, P., Bronson, R., Appella, E., and Alt, F.W. 2003. Developmental defects and p53 hyperacetylation in Sir2 homo$\log$ (SIRT1)-deficient mice. Proc. Natl. Acad. Sci. 100: 10794-10799.

Cowley, S.M., Iritani, B.M., Mendrysa, S.M., Xu, T., Cheng, P.F., Yada, J., Liggitt, H.D., and Eisenman, R.N. 2005. The $\mathrm{mSin} 3 \mathrm{~A}$ chromatin modifying complex is essential for embryogenesis and $\mathrm{T}$ cell development. Mol. Cell. Biol. (in press).

Dang, V.D., Benedik, M.J., Ekwall, K., Choi, J., Allshire, R.C, and Levin, H.L. 1999. A new member of the Sin3 family of corepressors is essential for cell viability and required for retroelement propagation in fission yeast. Mol. Cell. Biol. 19: $2351-2365$.

Dannenberg, J.-H., van Rossum, A., Schuijff, L., and te Riele, H. 2000. Ablation of the retinoblastoma gene family deregulates G(1) control causing immortalization and increased cell turnover under growth-restricting conditions. Genes \& Dev. 14: 3051-3064.

David, G., Turner, G.M., Yao, Y., Protopopov, A., and DePinho, R.A. 2003. mSin3-associated protein, $\mathrm{mSds} 3$, is essential for pericentric heterochromatin formation and chromosome segregation in mammalian cells. Genes \& Dev. 17: 23962405.

De Nadal, E., Zapater, M., Alepuz, P.M., Sumoy, L., Mas, G., and Posas, F. 2004. The MAPK Hog 1 recruits Rpd3 histone deacetylase to activate osmoresponsive genes. Nature 427: 370-374.

Fan, M., Rhee, J., St-Pierre, J., Handschin, C., Puigserver, P., Lin, J., Jaeger, S., Erdjument-Bromage, H., Tempst, P., and Spiegelman, B.M. 2004. Suppression of mitochondrial respiration through recruitment of p160 myb binding protein to PGC-1 $\alpha$ : Modulation by p38 MAPK. Genes \& Dev. 18: 278 289.

Fernandez, P.C., Frank, S.R., Wang, L., Schroeder, M., Liu, S., Greene, J., Cocito, A., and Amati, B. 2003. Genomic targets of the human c-Myc protein. Genes \& Dev. 17: 1115-1129.

Fischle, W., Wang, Y., and Allis, C.D. 2003. Histone and chromatin cross-talk. Curr. Opin. Cell. Biol. 15: 172-183.

Fleischer, T.C., Yun, U.J., and Ayer, D.E. 2003. Identification and characterization of three new components of the mSin3A corepressor complex. Mol. Cell. Biol. 23: 34563467.

Helbing, C.C., Veillette, C., Riabowol, K., Johnston, R.N., and Garkavtsev, I. 1997. A novel candidate tumor suppressor, ING1, is involved in the regulation of apoptosis. Cancer Res. 57: $1255-1258$.

Huang, Y., Myers, S.J., and Dingledine, R. 1999. Transcriptional repression by REST: Recruitment of Sin3A and histone deactylase to neuronal genes. Nat. Neurosci. 8: 67-72.

Jazayeri, A., McAinsh, A.D., and Jackson, S.P. 2004. Saccharomyces cerevisiae Sin3p facilitates DNA double-strand break repair. Proc. Natl. Acad. Sci. 101: 1644-1649.

Johnstone, R.W. and Licht, J.D. 2003. Histone deacetylase inhibitors in cancer therapy: Is transcription the primary target? Cancer Cell 4: 13-18.

Jones, M.H., Hamana, N., and Shimane, M. 2000. Identification and characterization of BPTF, a novel bromodomain transcription factor. Genomics 63: 35-39.

Jordan-Sciutto, K.L., Dragich, J.M., Rhodes, J.L., and Bowser, R. 1999. Fetal Alz-50 clone 1, a novel zinc finger protein, binds a specific DNA sequence and acts as a transcriptional regulator. J. Biol. Chem. 274: 35262-35268.

Juan, L.J., Shia, W.J., Chen, M.H., Yang, W.M., Seto, E., Lin, Y.S., and $\mathrm{Wu}, \mathrm{C} . \mathrm{W} .2000$. Histone deacetylases specifically downregulate p53-dependent gene activation. I. Biol. Chem. 275: 20436-20443.

Kim, H., Lee, J.E., Cho, E.J., Liu, J.O., and Youn, H.D. 2003. Menin, a tumor suppressor, represses JunD-mediated transcriptional activity by association with an mSin3A-histone deacetylase complex. Cancer Res. 63: 6135-6139.

Knoepfler, P.S. and Eisenman, R.N. 1999. Sin meets NuRD and other tails of repression. Cell 99: 447-450.

Koipally, J., Renold, A., Kim, J., and Georgopoulos, K. 1999. Repression by Ikaros and Aiolos is mediated through histone deacetylase complexes. EMBO J. 18: 3090-3100. 
Kuzmichev, A., Zhang, Y., Erdjument-Bromage, H., Tempst, P., and Reinberg, D. 2002. Role of the Sin3-histone deacetylase complex in growth regulation by the candidate tumor suppressor p33(ING1). Mol. Cell. Biol. 22: 835-848.

Lagger, G., O'Carroll, D., Rembold, M., Khier, H., Tischler, J., Weitzer, G., Schuettengruber, B., Hauser, C., Brunmeir, R., Jenuwein, T., et al. 2002. Essential function of histone deacetylase 1 in proliferation control and CDK inhibitor repression. $E M B O$ J. 21: 2672-2681.

Lagger, G., Doetzlhofer, A., Schuettengruber, B., Haidweger, E., Simboeck, E., Tischler, J., Chiocca, S., Suske, G., Rotheneder, H., Wintersberger, E., et al. 2003. The tumor suppressor p53 and histone deacetylase 1 are antagonistic regulators of the cyclin-dependent kinase inhibitor p21/ WAF1/CIP1 gene. Mol. Cell. Biol. 23: 2669-2679.

Laherty, C.D., Yang, W.M., Sun, J.M., Davie, J.R., Seto, E., and Eisenman, R.N. 1997. Histone deacetylases associated with the $\mathrm{mSin} 3$ corepressor mediate mad transcriptional repression. Cell 89: 349-356.

Lai, A, Kennedy, B.K., Barbie, D.A., Bertos, N.R., Yang, X.J., Theberge, M.C., Tsai, S.C., Seto, E., Zhang, Y., Kuzmichev, A., et al. 2001. RBP1 recruits the mSIN3-histone deacetylase complex to the pocket of retinoblastoma tumor suppressor family proteins found in limited discrete regions of the nucleus at growth arrest. Mol. Cell. Biol. 8: 2918-2932.

Lakso, M., Pichel, J.G., Gorman, J.R., Sauer, B., Okamoto, Y., Lee, E., Alt, F.W., and Westphal, H. 1996. Efficient in vivo manipulation of mouse genomic sequences at the zygote stage. Proc. Natl. Acad. Sci. 93: 5860-5865.

Lee, S.K., Kim, J.H., Lee, Y.C., Cheong, J., and Lee, J.W. 2000. Silencing mediator of retinoic acid and thyroid hormone receptors, as a novel transcriptional corepressor molecule of activating protein-1, nuclear factor- $\mathrm{kB}$, and serum response factor. J. Biol. Chem. 275: 12470-12474.

Li, C. and Wong, W. 2001. Model-based analysis of oligonucleotide arrays: Expression index computation and outlier detection. Proc. Natl. Acad. Sci. 98: 31-36.

Luo, R.X., Postigo, A.A., and Dean, D.C. 1998. Rb interacts with histone deacetylase to repress transcription. Cell 92: 463473.

Luo, J., Su, F., Chen, D., Shiloh, A., and Gu, W. 2000. Deacetylation of p53 modulates its effect on cell growth and apoptosis. Nature 408: $377-381$.

Luo, J., Nikolaev, A.Y., Imai, S., Chen, D., Su, F., Shiloh, A., Guarente, L., and Gu, W. 2001. Negative control of p53 by Sir2 $\alpha$ promotes cell survival under stress. Cell 107: 137-148.

Magnaghi-Jaulin, L., Groisman, R., Naguibneva, I., Robin, P., Lorain, S., Le Villain, J.P., Troalen, F., Trouche, D., and Harel-Bellan, A. 1998. Retinoblastoma protein represses transcription by recruiting a histone deacetylase. Nature 391: 601-605.

Matys, V., Fricke, E., Geffers, R., Gossling, E., Haubrock, M., Hehl, R., Hornischer, K., Karas, D., Kel, A.E., Kel-Margoulis, O.V., et al. 2003. TRANSFAC@: Transcriptional regulation, from patterns to profiles. Nucleic Acids Res. 31: 374-378.

Meehan, W.J., Samant, R.S., Hopper, J.E., Carrozza, M.J., Shevde, L.A., Workman, J.L., Eckert, K.A., Verderame, M.F., and Welch, D.R. 2004. Breast cancer metastasis suppressor 1 (BRMS1) forms complexes with retinoblastoma-binding protein 1 (RBP1) and the mSin3 histone deacetylase complex and represses transcription. J. Biol. Chem. 279: 1562-1569.

Melnick, A. and Licht, J.D. 2002. Histone deacetylases as therapeutic targets in hematologic malignancies. Curr. Opin. Hematol. 9: 322-332.

Murphy, M., Ahn, J., Walker, K.K., Hoffman, W.H., Evans, R.M., Levine, A.J., and George, D.L. 1999. Transcriptional repres- sion by wild-type p53 utilizes histone deacetylases, mediated by interaction with mSin3a. Genes \& Dev. 13: 24902501.

Nakayama, J., Xiao, G., Noma, K., Malikzay, A., Bjerling, P., Ekwall, K., Kobayashi, R., and Grewal, S.I. 2003. Alp13, an MRG family protein, is a component of fission yeast Clr6 histone deacetylase required for genomic integrity. $E M B O J$. 22: $2776-2787$.

Naviaux, R.K., Costanzi, E., Haas, M., and Verma, I.M. 1996. The pCL vector system: Rapid production of helper-free, high-titer, recombinant retroviruses. J. Virol. 70: 5701-5705.

Nicholson, D.W., Ali, A., Thornberry, N.A., Vaillancourt, J.P., Ding, C.K., Gallant, M., Gareau, Y., Griffin, P.R., Labelle, M., Lazebnik, Y.A., et al. 1995. Identification and inhibition of the ICE/CED-3 protease necessary for mammalian apoptosis. Nature 376: 37-43.

Orian, A., van Steensel, B., Delrow, J., Bussemaker, H.J., Li, L., Sawado, T., Williams, E., Loo, L.W., Cowley, S.M., Yost, C., et al. 2003. Genomic binding by the Drosophila Myc, Max, Mad/Mnt transcription factor network. Genes \& Dev. 17: 1101-1114.

Pile, L.A., Spellman, P.T., Katzenberger, R.J., and Wassarman, D.A. 2003. The SIN3 deacetylase complex represses genes encoding mitochondrial proteins: Implications for the regulation of energy metabolism. J. Biol. Chem. 278: 3784037848.

Pothof, J., van Haaften, G., Thijssen, K., Kamath, R.S., Fraser, A.G., Ahringer, J., Plasterk, R.H., and Tijsterman, M. 2003. Identification of genes that protect the C. elegans genome against mutations by genome-wide RNAi. Genes \& Dev. 17: 443-448.

Prasanth, S.G., Prasanth, K.V., Siddiqui, K., Spector, D.L., and Stillman, B. 2004. Human Orc2 localizes to centrosomes, centromeres and heterochromatin during chromosome inheritance. EMBO J. 23: 2651-2663.

Puigserver, P., Wu, Z., Park, C.W., Graves, R., Wright, M., and Spiegelman, B.M. 1998. A cold-inducible coactivator of nuclear receptors linked to adaptive thermogenesis. Cell 92: 829-839.

Rayman, J.B., Takahashi, Y., Indjeian, V.B., Dannenberg, J.-H., Catchpole, S., Watson, R.J., te Riele, H., and Dynlacht, B.D. 2002. E2F mediates cell cycle-dependent transcriptional repression in vivo by recruitment of an $\mathrm{HDAC} 1 / \mathrm{mSin} 3 \mathrm{~B}$ corepressor complex. Genes \& Dev. 16: 933-947.

Reiss, U., Oskouian, B., Zhou, J., Gupta, V., Sooriyakumaran, P., Kelly, S., Wang, E., Merrill Jr., A.H., and Saba, J.D. 2004. Sphingosine-phosphate lyase enhances stress-induced ceramide generation and apoptosis. J. Biol. Chem. 279: 12811290.

Ren, B., Cam, H., Takahashi, Y., Volkert, T., Terragni, J., Young, R.A., and Dynlacht, B.D. 2002. E2F integrates cell cycle progression with DNA repair, replication, and $\mathrm{G}(2) / \mathrm{M}$ checkpoints. Genes \& Dev. 16: 245-256.

Rodriguez, C.I., Buchholz, F., Galloway, J., Sequerra, R., Kasper, J., Ayala, R., Stewart, A.F., and Dymecki, S.M. 2000. Highefficiency deleter mice show that FLPe is an alternative to Cre-loxP. Nat. Genet. 2: 139-140.

Sakaguchi, K., Herrera, J.E., Saito, S., Miki, T., Bustin, M., Vassilev, A., Anderson, C.W., and Appella, E. 1998. DNA damage activates p53 through a phosphorylation-acetylation cascade. Genes \& Dev. 12: 2831-2841.

Schreiber-Agus, N. and DePinho, R.A. 1998. Repression by the $\operatorname{mad}(m x i 1)-\sin 3$ complex. Bioessays 20: 808-818.

Schreiber-Agus, N., Chin, L., Chen, K., Torres, R., Rao, G., Guida, P., Skoultchi, A.I., and DePinho, R.A. 1995. An amino-terminal domain of Mxil mediates anti-Myc onco- 
genic activity and interacts with a homolog of the yeast repressor SIN3. Cell 80: 777-786.

Schuettengruber, B., Simboeck, E., Khier, H., and Seiser, C. 2003. Autoregulation of mouse histone deacetylase 1 expression. Mol. Cell. Biol. 19: 6993-7004.

Siepel, A. and Haussler, D. 2005. Phylogenetic hidden Markov models. In Statistical methods in molecular evolution (ed. R. Nielsen), pp. 325-351. Springer, New York.

Sif, S., Saurin A.J., Imbalzano, A.N., and Kingston, R.E. 2001. Purification and characterization of $\mathrm{mSin} 3 \mathrm{~A}-$ containing Brg1 and hBrm chromatin remodeling complexes. Genes \& Dev. 15: 603-618.

Silverstein, R.A. and Ekwall, K. 2004. Sin3: A flexible regulator of global gene expression and genome instability. Curr. Genet. 47: 1-17.

Silverstein, R.A., Richardson, W., Levin, H., Allshire, R., and Ekwall, K. 2003. A new role for the transcriptional corepressor SIN3; regulation of centromeres. Curr. Biol. 13: 68-72.

Skowyra, D., Zeremski, M., Neznanov, N., Li, M., Choi, Y., Uesugi, M., Hauser, C.A., Gu, W., Gudkov, A.V., and Qin, J. 2001. Differential association of products of alternative transcripts of the candidate tumor suppressor ING1 with the mSin3/HDAC1 transcriptional corepressor complex. J. Biol. Chem. 276: 8734-8739.

Sternberg, P.W., Stern, M.J., Clark, I., and Herskowitz, I. 1987. Activation of the yeast $\mathrm{HO}$ gene by release from multiple negative controls. Cell 48: 567-577.

Vannier, D., Balderes, D., and Shore, D. 1996. Evidence that the transcriptional regulators SIN3 and RPD3, and a novel gene (SDS3) with similar functions, are involved in transcriptional silencing in S. cerevisiae. Genetics 144: 1343-1353.

Vaziri, H., Dessain, S.K., Ng Eaton, E., Imai, S.I., Frye, R.A., Pandita, T.K., Guarente, L., and Weinberg, R.A. 2001. hSIR2(SIRT1) functions as an NAD-dependent p53 deacetylase. Cell 107: 149-159.

Wang, R., Cherukuri, P., and Luo, J. 2005. Activation of Stat3 sequence-specific DNA binding and transcription by $\mathrm{p} 300 /$ CREB-binding protein-mediated acetylation. J. Biol. Chem. 280: $11528-11534$

Whitfield, M.L., Sherlock, G., Saldanha, A.J., Murray, J.I., Ball, C.A., Alexander, K.E., Matese, J.C., Perou, C.M., Hurt, M.M., Brown, P.O., et al. 2002. Identification of genes periodically expressed in the human cell cycle and their expression in tumors. Mol. Biol. Cell. 6: 1977-2000.

Xiao, H., Sandaltzopoulos, R., Wang, H.M., Hamiche, A., Ranallo, R., Lee, K.M., Fu, D., and Wu, C. 2001. Dual functions of largest NURF subunit NURF301 in nucleosome sliding and transcription factor interactions. Mol. Cell. 8: 531543.

Yang, X.J. 2004. Lysine acetylation and the bromodomain: A new partnership for signaling. Bioessays 26: 1076-1087.

Yuan, Z.L., Guan, Y.J., Chatterjee, D., and Chin, Y.E. 2005. Stat3 dimerization regulated by reversible acetylation of a single lysine residue. Science 307: 269-273.

Zilfou, J.T., Hoffman, W.H., Sank, M., George, D.L., and Murphy, M. 2001. The corepressor mSin3a interacts with the proline-rich domain of p53 and protects p53 from proteasome-mediated degradation. Mol. Cell. Biol. 21: 3974-3985. 


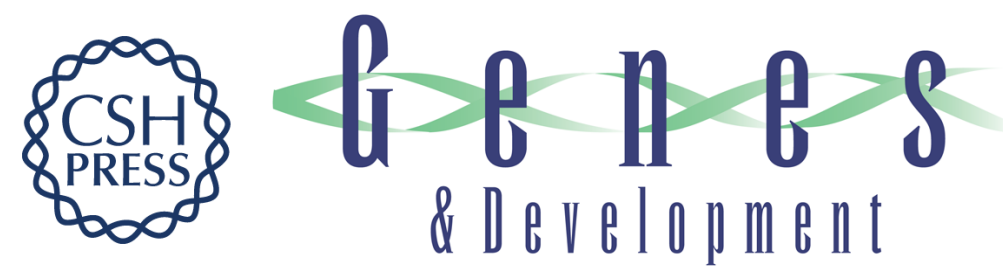

\section{mSin3A corepressor regulates diverse transcriptional networks governing normal and neoplastic growth and survival}

Jan-Hermen Dannenberg, Gregory David, Sheng Zhong, et al.

Genes Dev. 2005, 19:

Access the most recent version at doi:10.1101/gad.1286905

Supplemental http://genesdev.cshlp.org/content/suppl/2005/06/16/19.13.1581.DC1
Material

References This article cites 69 articles, 42 of which can be accessed free at:

http://genesdev.cshlp.org/content/19/13/1581.full.html\#ref-list-1

License

Email Alerting

Receive free email alerts when new articles cite this article - sign up in the box at the top

Service

right corner of the article or click here.

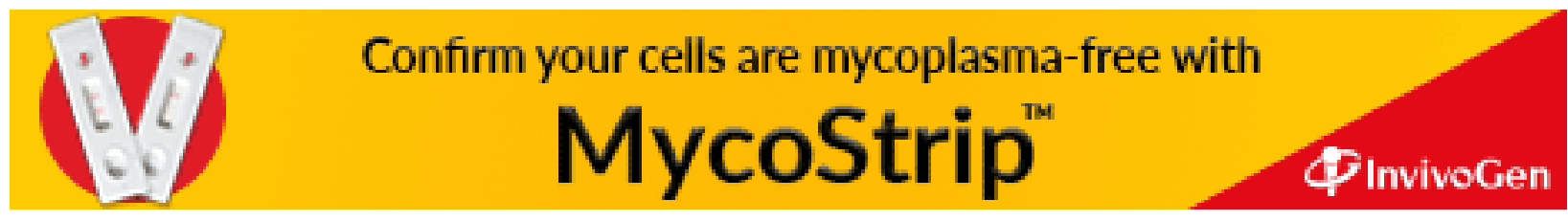

